\title{
1 Morpho-anatomical observations on Phyllanthus of Southwestern Bangladesh with two new
}

2 records for Bangladesh.

$3 \quad{ }^{1}$ Md. Sajjad Hossain Tuhin \& ${ }^{2}$ Md. Sharif Hasan Limon

$4 \quad{ }^{1,2}$ Forestry and Wood Technology Discipline, Khulna University, Khulna 9208, Bangladesh.

51 tuhin.taxon@gmail.com, ${ }^{2}$ limonsh@ fwt.ku.ac.bd

7 Abstract: An extensive floristic survey was done to annotate Phyllanthus of southwestern

8 Bangladesh from 2015 to 2018. In total, 2189 individuals of Phyllanthus were counted and

9 identified as eight different species (five herbs, two trees and a shrub). All species were examined

10 following both morphological and anatomical methods, based on taxonomic notes. The listed

11 species were Phyllanthus acidus, Phyllanthus amarus, Phyllanthus debilis, Phyllanthus emblica,

12 Phyllanthus niruri, Phyllanthus urinaria, Phyllanthus reticulatus and Phyllanthus virgatus.

13 Among them, Phyllanthus amarus and Phyllanthus debilis were listed for the first time from

14 Bangladesh during this study period.

15 Keyword: Angiosperm, Phyllanthus, taxonomy, distribution, Bangladesh, Phyllanthus amarus, 16 Phyllanthus debilis 


\section{Introduction}

Phyllantheace is a very common taxa found in Bangladesh. It is a large family of flowering plants, consisting of 59 accepted genera, 10 tribes, two subfamilies and about 2000 species worldwide (Hoffmann et. al. 2006). This family is the second largest segregation of Euphorbiaceae sensu lato (s.1.) among Pandaceae, Picrodendraceae, and Putranjivaceae (Savolainen et al. 2000; Samuel et al. 2005). Phyllanthus is the largest genera of Phyllanthaceae consisting approximately 1000 species. Most of the Phyllanthus species are distributed in tropical and subtropical region (Sarin et al. 2014; Calixto et al. 1998). Previously, Phyllanthus represented 11 species (5 herbs, 4 shrubs and 2 trees) in Bangladesh (Ahamed et al. 2008). Most of the regional literatures of this region ensured a valuable contribution of it to the regional flora (Uddin \& Hassan 2010; Islam et al. 2009; Rahman et. al. 2015; Tutul et. al. 2010). In addition to that, most of them are known to have economic and medicinal uses. Some of them had already been used in ethno-medicine and extraction of antioxidant and other industrial chemicals (Ali et al. 2006; Cesari et al. 2015; Gebhardt et al. 2003; Okafor et al. 2008; Patel et al. 2011; Thyagarajan et al. 1988). So, it is very important to conserve those species in terms of ecology and economy. But, many of the Phyllanthus sp. have a close morphological characteristics, which made them very difficult to differentiate at the species level (Kandavel et al. 2011; Webster 1956). Meanwhile, conservation demands proper identification to study its ecology and distribution. In this current study, available Phyllanthus individuals were collected from the south-western part of Bangladesh and attempted to identify at species level with morphological and anatomical features.

\section{Materials and Methods}

\section{Study Site}


Khulna division lies between $21.643^{\circ} \mathrm{N}$ to $24.181^{\circ} \mathrm{N}$ and $88.56^{\circ} \mathrm{E}$ to $89.943^{\circ} \mathrm{E}$ (Fig. 1). It

40

41

42 experiences a tropical climatic condition with a mild winter from October to March, hot and humid summer in March to June and humid, warm rainy monsoon in June to October. Temperature varies all the year round, in January and December temperature falls to the lowest $12-15^{\circ} \mathrm{C}$ and it reached highest in April-June at $41-45^{\circ} \mathrm{C}$. Daily relative humidity lied between 50-90\%, which became lowest in evening and highest in morning. Rainy season occurred here from June to October. Maximum precipitation was experienced in July with 20-25 days of rain with $368 \mathrm{~mm}$ precipitation. Wind speed is also variable here. Wind speed shows higher in the months of April, May, June July and August. In those months average wind speed is over $5 \mathrm{Km} / \mathrm{h}$. In the month of May the average wind speed reaches height around $8 \mathrm{~km} / \mathrm{h}$. Maximum wind speed also reaches higher in this month is around $80-90 \mathrm{~km} / \mathrm{h}$. December is the calmest month of the year, wind speed is lowest here. Average daily wind speed during this month is $2 \mathrm{~km} / \mathrm{h}$ and maximum reaches only 26 km/h (Bangladesh Bureau of Statistics 2014).

\section{Fig 1: Map of the study area}

\section{Sampling design}

The study was carried out at nine administrative districts (namely, Khulna, Kushita, Jessore, Bagherhat, Chuadanga, Satkhira, Magura, Meherpur and Jhinaidha) of southwestern of Bangladesh from April 2015 to August 2018. In total, 45 sites were selected from those 9 districts (5 sites from each) by opportunistic sampling technique (Fig. 01, table 1) (Milchunas et al. 1992). Habitat, diversity of Phullanthus and population size were considered to select the study sites. Standard herbarium technique (Hyland 1972; Rahman et al. 2013) was used to collect the herbarium specimen for analysis. Live specimens were photographed by Celestron handheld digital microscope and Nikon-3200D camera with Nikkor 18-55mm AF-S DX, Nikkor 55-300mm 
AF-S DX and Micro-Nikkor $105 \mathrm{~mm}$ FX AF lenses. We recorded GPS quadrate for all surveyed sites with a GPS device (Garmin GPSMAP 76CSx). Image J (1.52a) was used to record morphological measurements and image analysis. Herbarium sheets were prepared and deposited to FWT herbarium to conserve for future use. We did not collect any endangered angiosperm or sample from any protected areas, hence no permission was required for the collections. Collected specimens were analyzed and identified based on key provided by Hooker (1890), Prain (1904), Kanjilal et al. (1938), Deb (1983), Matthew (1999) and Ahmed et. al. (2008).

Table 1: A list of locations in the southwestern region of Bangladesh surveyed during the study period

\section{Result}

2189 individuals of Phyllanthus were examined and classified into eight different species from southwestern part of Bangladesh. Among these, five were herbs, two trees and a shrubs. Expect Phyllanthus debilis all the species were well distributed throughout the study area. Meanwhile, Phyllanthus niruri, Phyllanthus urinaria, Phyllanthus amarus and Phyllanthus reticulatus were very abundant in the study sites. But Phyllanthus virgatus were found in Jessore-Chuadangha belt and absent in Khulna, Satkhira and Bhagerhat (table 2). Apart from these, Phyllanthus acidus and Phyllanthus emblica could be listed as a plantation species as they were absent at natural habitats. In addition to it, Phyllanthus amarus and Phyllanthus debilis were listed for the first time from Bangladesh at current study.

Table 2: List and distribution of the listed Phyllanthus sp. at current study 
83 Synonyms: Averrhoa acida L.: In: Sp. Pl.: 428 (1753), Cicca acida (L.) Merr.: In: Interpr. Herb.

84 Amboin.: 314 (1917), Cicca acidissima Blanco: In: Fl. Filip.: 700 (1873), Cicca disticha L.: In:

85 Mant. Pl. 1: 124 (1767), Cicca nodiflora Lam.: In: Encycl. 2: 1 (1786), Cicca racemosa Lour.: In:

86 Fl. Cochinch.: 556 (1790), Diasperus acidissimus (Blanco) Kuntze: In: Revis. Gen. Pl. 2: 598

87 (1891), Phyllanthus acidissimus (Blanco) Müll. Arg.: In: Linnaea 32: 50 (1863), Phyllanthus cicca

88 Müll. Arg.: In: Linnaea 32: 50 (1863), Phyllanthus cicca var. bracteosa Müll.Arg.: In: Linnaea 32:

8950 (1863), Phyllanthus cochinchinensis (Lour.) Müll.Arg., nom. illeg.: In: Prodr. 15(2): 417

90 (1866), Phyllanthus distichus (L.) Müll.Arg., nom. illeg.: In: Prodr. 15(2): 413 (1866), Phyllanthus

91 distichus f. nodiflorus (Lam.) Müll.Arg.: In: Prodr. 15(2): 414 (1866), Phyllanthus longifolius

92 Jacq.: In: Pl. Hort. Schoenbr. 2: 36 (1797), Tricarium cochinchinense Lour.: In: Fl. Cochinch.: 557

93 (1790).

A Monoecious, glabrous, deciduous, small sized tree, up to $15 \mathrm{~m}$ high; branches stout, leafless,

95 with slender deciduous leafy branchlets at the end; bark brownish. Leaves distichous, alternate,

97 ovate-lanceolate, $3-8 \mathrm{~mm}$ long and $1-3.5 \mathrm{~mm}$ wide, leathery, acute to acuminate at apex, rounded reddish, at dense clusters forming slender, glabrous, in interrupted racemes, arising along the stem and branches. Male flowers are minute, red; staminate, stamen 4, free, 2 shorter; disc gland 4, smooth, diameter 0.4-0.7mm; pedicellate, pedicels 1-3 mm long and less than $1 \mathrm{~mm}$ width, slender; sepal 4, suborbicular, 0.8-1mm long, entire. Female flowers are very few, pedicellate; sepal 4, 1- 
fleshy, pale yellowish green, endocarp crustaceous. Seeds reddish brown, trigonous or convex, 24mm long. Flowering and fruiting: March-July (Fig. 2).

\section{Phyllanthus amarus Schumach. \& Thonn.: In: Beskr. Guin. Pl.: 421 (1827)}

Synonyms: Phyllanthus swartzii Kostel.: In: Allg. Med.-Pharm. Fl. 5: 1771 (1836), Phyllanthus niruroides var. madagascariensis Leandri, nom. inval.: In: Notul. Syst. (Paris) 7: 184 (1839), Phyllanthus scabrellus Webb: In: Niger Fl.: 175 (1849), Phyllanthus nanus Hook.f.: In: Fl. Brit. India 5: 298 (1887), Diasperus nanus (Hook.f.) Kuntze: In: Revis. Gen. Pl. 2: 601 (1891), Phyllanthus amarus var. baronianus Leandri, nom. inval.: In: Notul. Syst. (Paris) 7: 183 (1939), Phyllanthus niruri var. amarus (Schumach. \& Thonn.) Leandri: In: Fl. Madag. 111: 73 (1958), Phyllanthus niruri var. baronianus (Leandri) Leandri, nom. inval.: In: Fl. Madag. 111: 74 (1958), Phyllanthus niruri var. scabrellus (Webb) Müll.Arg.: In: Linnaea 32: 43 (1963).

A Monoecious erect annual herb, up to $1 \mathrm{~m}$ high; stems often branching phyllanthoid with age, branches angular, 3-10 $\mathrm{cm}$ long (can reach up to $15 \mathrm{~cm}$ ), usually with 20-42 leaves. Leaves alternate, membranous, oblong or elliptic-oblong; 3-8 $\mathrm{mm}$ long and 2-5mm wide, membranous or thinly papery, base rounded, apex obtuse or rounded and often apiculate; stipulate, lanceolate, scarious, acute, $0.8-1 \mathrm{~m}$ long; petiolate, petioles very short $0.2-0.7 \mathrm{~mm}$ long; entire leaf margin, lateral nerves 4-7 pairs, slightly conspicuous abaxially; indistinct, dark green above, paler and greyish beneath. Flower bisexual, light yellow, very numerous, axillary, along lower part of leafy shoots usually male, those in middle usually often bisexual with 1 female and 1 male flower, those toward branchlet apex often female. Male flowers are staminate, stamen 3, filamentous, filaments connate; pedicellate, pedicels $0.5-1 \mathrm{~mm}$ long and less than $0.4 \mathrm{~mm}$ width; sepal 5, 0.2-0.5 mm long, elliptic or obovate, apex acute; midrib yellowish green, margin membranous; disc gland 5, lobulated, orbicular or obovate, filaments completely connate into a column, 0.2-0.3 mm high; 
128

129

130

131

132

133

134

135

136

137

138

139

140

141

142

143

144

145

146

147

148

149

150 anthers sessile, 1 often reduced to a single anther sac (or sometimes only 2 functional anthers present), anther sacs divergent, slits completely confluent, horizontal. Female flower are pedicellate, pedicle $0.5-1.0 \mathrm{~mm}$ long; sepal 5, obovate to obovate-oblong, margin membranous, 0.8-1 mm long and 0.4-0.5 mm width, apex obtuse or acute; lobulate, 5 lobed, nectary disk thin and flat or subulate; ovary globose-triangular, $0.5 \times 0.6 \mathrm{~mm}$, smooth; styles free, erect or ascending, apex shallowly bifid. Fruit a capsule, depressed-globose, approximately 1-1.6 $\mathrm{mm}$ in diameter, dilated at apex, the surface smooth, explosively dehiscent. Seeds sharply 3-angled, 0.8$1 \mathrm{~mm}$ long and 0.6-0.8 mm width, light brown or yellowish brown, longitudinally 5-6 ribs, minutely transversely striate with hygroscopic cells; Flowering and fruiting: July- October (Fig. 3).

\section{Phyllanthus debilis J.G.Klein ex Willd.: In: Sp. Pl. 4: 582 (1805)}

Synonyms: Phyllanthus niruri var. javanicus Müll.Arg.: In: Linnaea 32: 43 (1863), Phyllanthus niruri var. debilis (J.G.Klein ex Willd.) Müll.Arg.: In: Prodr. 15(2): 407 (1866), Diasperus debilis (J.G.Klein ex Willd.) Kuntze: In: Revis. Gen. Pl. 2: 601 (1891), Phyllanthus boninsimae Nakai: In: Bot. Mag. (Tokyo) 26: 96 (1912), Phyllanthus leai S.Moore: In: J. Linn. Soc., Bot. 45: 217 (1920).

A Monoecious erect annual herb, up to $60 \mathrm{~cm}$ high; stems often branching phyllanthoid with age, branches angular, 3-8 $\mathrm{cm}$ long (can reach up to $12 \mathrm{~cm}$ ), usually with 12-35 leaves. Leaves alternate, stipulate, lanceolate, scarious, acute, $1.0-1.5 \mathrm{~mm}$ long; petiolate, petioles very short $0.3-1 \mathrm{~mm}$ long; narrowly elliptic to lanceolate, $8-20 \mathrm{~mm}$ long and 2-5mm wide, acute to acuminate at the apex and cuneate to acute at the base, entire leaf margin, membranous, lateral nerves 5-7 pairs, indistinct, dark green above, paler and greyish beneath. Flower bisexual, light yellow, very numerous, axillary. Male flowers 3-4 racemose cymes arising first 2-4 node of the branches; staminate, 
151

152

153

154

155

156

157

158

159

stamen 3, filamentous, filaments connate; pedicellate, pedicels $0.4-0.5 \mathrm{~mm}$ long and less than 0.5 mm width; sepal 6, 0.5-0.7 mm long, obovate, rounded, midrib yellowish green; disc gland 6, lobulate; anther horizontal. Female flower solitary in the node above male flowers; pedicellate, pedicle 1-1.6 mm long; sepal 6, obovate to oblong, rounded, 1.2-1.6 mm long and 0.4-0.6 mm width, lobulate, 6 lobed, margin whitish and scarious, nectary disk thin and flat, deeply lobed into 6-10, bifid; ovary subglobose, 0.8-1.1 mm diameter, smooth, styles minute and free. Fruit a capsule, depressed-globose, approximately 2-2.2 $\mathrm{mm}$ in diameter, the surface smooth, explosively dehiscent. Seeds angled ca. $1 \mathrm{~mm}$ long and $0.6 \mathrm{~mm}$ width, longitudinally 6-7 ribs and fine transverse striations on back, pale yellowish brown. Flowering and fruiting: March- June (Fig. 4).

\section{Phyllanthus emblica L.: In: Sp. Pl.: 982 (1753)}

Synonyms: Cicca emblica (L.) Kurz: In: Forest Fl. Burma 2: 352 (1877), Diasperus emblica (L.) Kuntze: In: Revis. Gen. Pl. 2: 599 (1891), Dichelactina nodicaulis Hance: In: Ann. Bot. Syst. 3: 376 (1853), Emblica arborea Raf.: In: Sylva Tellur.: 91 (1838), Emblica officinalis Gaertn.: In: Fruct. Sem. Pl. 2: 122 (1970), Phyllanthus glomeratus Roxb. ex Benth., nom. nud.: In: Numer. List: n. ${ }^{\circ} 7903$ (1847), Phyllanthus mairei H.Lév.: In: Bull. Acad. Int. Géogr. Bot. 25: 23 (1915), Phyllanthus mimosifolius Salisb.: In: Prodr. Stirp. Chap. Allerton: 391 (1796), Phyllanthus taxifolius D.Don: In: Prodr. Fl. Nepal.: 63 (1825).

A Monoecious, phuescent or glabrous, deciduous, medium sized tree, up to $25 \mathrm{~m}$ high; bark brownish; main stems terete, sparsely lenticellate; leafy shoots angular, tawny pubescent. Leaves distichous, alternate, stipulate, stipules triangular-ovate, 0.8-1.5 mm; petiolate, petioles very short 0.3-0.8mm long, attenuate to acuminate, ciliolate, brown; leaf blade oblong or linear-oblong, 8$25 \mathrm{~mm}$ long and $1.5-5 \mathrm{~mm}$ wide, papery to leathery, paler abaxially, green adaxially, drying reddish or brownish, base shallowly cordate and slightly oblique, margin narrowly revolute, apex truncate, 
174 rounded or obtuse, mucronate or retuse at tip; lateral veins 4-9 pairs, sometimes indistinct. Flower

175 bisexual, in axillary cymes, with many male flowers and sometimes 1 or 2 larger female flowers

176 per cyme. Male flowers are staminate, stamen 3, filamentous, filaments coherent into a central

177 column, 0.3-0.7mm long; anthers erect, obolong, 0.5-1 mm long, horizontal; pedicellate, pedicels

178 1-3 mm long and less than $1 \mathrm{~mm}$ width, slender; sepal 6, 1.5-2.5 mm long and 0.5-1mm wide,

179 obovate or spathulate, subequal, obtuse or rounded, entire, midrib yellowish green with a pale 180 hyaline margin; disc gland 6, smooth, 0.2-0.5mm diameter. Female flowers are pedicellate, pedicle 181 ca. 0.7mm long; sepal 6, oblong or spathulate, 1.5-2.5 mm long and 0.6-1.3 mm width, apex obtuse 182 or rounded, thicker, margin membranous; ovary ovoid, ca. $1.5 \mathrm{~mm}$, 3-celled; styles 3, stout, fleshy, 1.5-4 mm long, connate at base, apex deeply bifid, lobes divided at tip. Fruit a drupe, subglobose, smooth, 1-1.3 cm in diameter, exocarp fleshy, pale green or yellowish white, endocarp crustaceous. Seeds reddish, trigonous or plano-convex, 3-6mm long and 2-3 $\mathrm{mm}$ wide. Flowering and fruiting: March-October (Fig. 5)

Synonyms: Urinaria erecta Medik.: In: Malvenfam.: 80 (1787), Nymphanthus niruri (L.) Lour.: апnиa Raf .: In: Sylva Tellur.: 91 (1838), Niruris indica Raf.: In: Sylva Tellur.: 91 (1838), Phyllanthus moeroris Oken: In: Allg. Naturgesch. 3(3): 1601 (1841), Phyllanthus filiformis Pav. ex Baill.: In: Recueil Observ. Bot. 1: 29 (1860), Phyllanthus ellipticus Buckley, nom. illeg.: In: Müll.Arg.: In: Linnaea 32: 41(1863), Phyllanthus niruri var. genuinus Müll.Arg., nom. inval.: In: 
A Monoecious erect annual herb, up to $70 \mathrm{~cm}$ high; stems often branching phyllanthoid with age, branches angular, 2-5 cm long (can reach up to 8cm), usually with 13-26 leaves. Leaves alternate, stipulate, lanceolate, scarious, acute, 1.0-1.2mm long; petiolate, petioles very short 0.3-1 mm long; elliptic-obolong to elliptic-oblanceolate, 5-12 $\mathrm{mm}$ long and 2-5mm wide, obtuse or rounded at the apex and tapering to the base, entire leaf margin, membranous, lateral nerves 4-7 pairs, indistinct, dark green above, paler and greyish beneath. Flower bisexual, light yellow, very numerous, filaments united into a short column; pedicellate, pedicels are 0.9-1 mm long and less than $0.5 \mathrm{~mm}$ width; sepal 6, 0.6-0.7 mm long, obovate, rounded, midrib yellowish green; disc gland 6, lobulated, verruculose; anther horizontal. Female are pedicellate, pedicle 1.4-1.9 mm long; sepal 6, unequal, oblong to obolanceolate, rounded, white, $1.0-1.5 \mathrm{~mm}$ long and 0.4-0.5 mm width, lobulate, 6 lobed; others linear and entire; ovary subglobose, 0.8-1 mm diameter, smooth, styles minute and free,

211 adpressed or ascending, lobes recurved. Fruit a capsule, trilobite-subglobose, approximately 1.5$212 \quad 2.5 \mathrm{~mm}$ in diameter, the surface smooth, olivaceous or stramineous. Seeds angled ca. $1 \mathrm{~mm}$ long 213 and $0.6 \mathrm{~mm}$ width, longitudinally 7-8 ribs on back, ochreous-fulvous, dark yellowish brown. 214 Flowering and fruiting: August- October (Fig. 6).

216 Synonyms: Anisonema reticulatum (Poir.) A.Juss.: In: Euphorb. Gen.: 4 (1824), Cicca reticulata

217 (Poir.) Kurz: In: Forest Fl. Burma 2: 354 (1877), Diasperus reticulatus (Poir.) Kuntze: In: Revis.

218 Gen. Pl. 2: 600 (1891), Kirganelia reticulata (Poir.) Baill.: In: Étude Euphorb.: 613 (1858), 
Anisonema dubium Blume: In: Bijdr. Fl. Ned. Ind.: 589 (1826), Anisonema intermedium Decne.:

In: Nouv. Ann. Mus. Hist. Nat. 4: 482 (1831), Anisonema jamaicense (Griseb.) Griseb.: In: Fl.

A Monoecious erect perineal shrub, up to $6 \mathrm{~m}$ high; bark peeling or flaking, grayish-brown; leaves and pedicels puberulous or plabrous, yellowish green; usually with 11-28 leaves. Leaves alternate, stipulate, stipule subulate-lanceolate, $0.8-2 \mathrm{~mm}$ long, acuminate, truncate at base; petiolate, petioles very short $1.5-3 \mathrm{~mm}$ long, chartaceous; leaf blade varies, mostly elliptic to ovate; $15-26 \mathrm{~mm}$ long and $5-15 \mathrm{~mm}$ wide, obtuse to rounded at the apex and cuneate at the base, entire leaf margin, membranous, lateral nerves 5-9 pairs, indistinct, tertiary vines reticulate; dark green above, paler and greyish beneath. Flowers an axillary fascicle, rarely a cyme, with 2-10 male and 1 or 2 female flowers. Male flowers are staminate, stamen 5, outer 2 free, inner 3 short and united at base, longer, filamentous stout; pedicellate, pedicels are 6-10 mm long; sepal 5-6, in 2 series, ovate or obovate, unequal, entire, 0.6-1.5 mm long; disc gland 5, scale like, diameter ca. 0.5mm; anther longitidunally dehiscent, less than ca. $0.5 \mathrm{~mm}$ in diameter. Female are pedicellate, pedicle $3-8 \mathrm{~mm}$

237 long, slender; sepal 5-6, unequal, in 2 or 3 series, oblong-elliptic or suborbicular, 1-1.5 mm long and 0.7-1.2 mm width; disk glands 5-6, free, obolong or obovate, flattened; ovary 4-12 celled, smooth, ca. 1mm; styles free, bifid at apex. Fruit a berry, globose to oblate, c 4-6 mm wide, greenish at initial stage, black and dark purplish at maturity, 4-12-celled, 8-16-seeded. Seeds 
Trans. \& Proc. Bot. Soc. Edinburgh 20: 329 (1895), Phyllanthus muricatus Benth., nom. nud.: In:

Leafl. Philipp. Bot. 7: 2649 (1915).

A Monoecious erect annual herb, sometimes perineal, glabrous or puberulous, up to $1 \mathrm{~m}$ high, tems alternate, stipulate, ovate-lanceolate, $1.0-1.5 \mathrm{~mm}$ long; petiolate, petioles very short 0.3-0.5 mm

258 long; leaf blade linear or oblong to oblong-obovate, 5-20 $\mathrm{mm}$ long and 2-7 $\mathrm{mm}$ wide, acute apex, mucronulate, conspicuously ariculate or obtuse base; lateral nerves 4-6 pairs, conspicuous, 260 glaucous beneath; dark greenish brown above, paler and greyish beneath. Flower bisexual, light 261 yellow to reddish yellow, axillary, glomerules on deciduous branch. Male flowers are pedicellate, 262 pedicels are $0.5 \mathrm{~mm}$ long, ariculate above the middle; staminate, stamen 3 , filamentous, filaments united into a slender column; sepal 6, 0.3-0.6 mm long, elliptic to obolong-obovate, obtuse at apex; 
but not fused together. Female are solitary, pedicellate, pedicle 0.2-0.5 mm long; sepal 6, subequal, oblong-lanceolate, obtuse or subacute, subglabrous, yellowish with a reddish-olive midrib, 0.7-1.1 mm long and 0.2-0.5 mm width; nectary disk flat, entire; styles 3 , minute and free, adpressed to the top of the ovary; ovary bifid, lobes recurved. Fruit a capsule, globose, 2-2.5 $\mathrm{mm}$ in diameter, with reddish blotches, scurfy-tuberculate. Seed 3-sided, 1-1.2mm long and 0.9-1 mm wide, light grayish brown, with 12-15 sharp transverse ridges on back and sides, often with 1-3 deep circular pits on side. Flowering and fruiting: April-October (Fig. 8).

\section{Phyllanthus virgatus G.Forst.: In: Fl. Ins. Austr.: 65 (1786)}

Synonyms: Phyllanthus simplex var. virgatus (G.Forst.) Müll.Arg., nom. illeg.: In: Linnaea 32: 32 (1863), Diasperus virgatus (G.Forst.) Kuntze: In: Revis. Gen. Pl. 2: 597 (1891), Diasperus beckleri (Müll.Arg.) Kuntze: In: Revis. Gen. Pl. 2: 598 (1891), Diasperus conterminus (Müll.Arg.) Kuntze: In: Revis. Gen. Pl. 2: 599 (1891), Diasperus depressus Kuntze: In: Revis. Gen. Pl. 2: 599 (1891), Diasperus minutiflorus (F.Muell. ex Müll.Arg.) Kuntze: In: Revis. Gen. Pl. 2: 600 (1891), Diasperus miquelianus (Müll.Arg.) Kuntze: In: Revis. Gen. Pl. 2: 600 (1891), Diasperus pedunculatus (Kostel.) Kuntze: In: Revis. Gen. Pl. 2: 597 (1891), Macraea oblongifolia Wight: In: Icon. Pl. Ind. Orient. 5(2): 27 (1852), Melanthesa anceps (Vahl) Miq.: In: Fl. Ned. Ind. 1(2): 371 (1859), Phyllanthus anceps Vahl: In: Symb. Bot. 2: 95 (1791), Phyllanthus beckleri Müll.Arg.: In: Linnaea 34: 74 (1865), Phyllanthus eboracensis S.Moore: In: J. Linn. Soc., Bot. 45: 216 (1920), Phyllanthus patens Miq. ex Müll.Arg.: In: Linnaea 32: 34 (1863), Phyllanthus simplex Retz.: In: Observ. Bot. 5: 29 (1789), Phyllanthus simplex var. myrtifolius Domin: In: Biblioth. Bot. 22: 876 (1927), Phyllanthus weinlandii K.Schum.: In: Fl. Schutzgeb. Südsee, Nachtr.: 287 (1905).

A monoecious erect annual herb, sometimes perineal, up to $70 \mathrm{~cm}$ high, glabrous throughout, branchlets angled, more or less compressed, smooth; stem usually slightly woody at base. Leaves 
stipulate, stipule $0.8-1.0 \mathrm{~mm}$ long, membranous, ovate, acuminate at apex, prominently and asymmetrically auriculate at base; petiolate, petioles very short 0.6-0.9 mm long; leaf blade linearlanceolate, oblong or narrowly elliptic, 5-18 $\mathrm{mm}$ long and 2-8mm wide, obtuse or acute at the apex, rounded and slightly oblique at the base, entire leaf margin, membranous, lateral nerves obscure at both surface. Flower bisexual, axillary fascicled, usually 2-4 male and one female per fascicle.Male flowers are pedicellate, pedicels are 0.9-1 mm long; sepal 6, 0.4-0.6 mm long, broadly elliptic, ovate or orbicular, obolong; staminate, stamen 3, filamentous, filaments are 0.3$0.5 \mathrm{~mm}$ long; disc gland 6, lobulated; anther subglobose, $0.2-0.3 \mathrm{~mm}$ in diameter, horizontally dehiscent. Female are pedicellate, pedicle 3-5 mm long; sepal 6, subequal, ovate-oblong, acute to obtuse, margin slightly white-membranous, reflected in fruits, purple, 0.7-1.0 mm long, lobulate, 6 lobed; nectary disk thin and flat, orbicular,entire or subentire, ca. $0.6 \mathrm{~mm}$ diameter; ovary globose, 0.2-3 mm diameter, , bifid; smooth, styles minute and free, 3-celled, ca. $0.3 \mathrm{~mm}$ long, revolute. Fruiting occurred at pedicels, fruiting pedicels are 5-12 $\mathrm{mm}$ long; fruit is a capsule, capsules oblate, 2-3 mm in diameter, purple, with raised scales or smooth. Seeds trigonous, 1.2$1.5 \mathrm{~mm}$, finely warty. Flowering and fruiting: May- October (Fig. 9).

Table 3: Morphological comparisons among studied Phyllanthus.

\section{Key to identify the Phyllanthus of South-western Bangladesh}

1.1 Branching phyllanthoid .2 2.1 Small to medium sized tree, up 15 m. Fruit's endocarp fleshy .3 3.1 Fruit is a drupe, stamen 4, male flower sepal 4 (radish), steam without non-glandular hair 1. P. acidus 3.2 Fruit is a capsule, stamen 3, male flower sepal 6 (white), steam with non-glandular hair. 4. P. emblica 


\section{Anatomical observation}

The epidermis of the studied eight species was one to three layer. The mesophylls are differentiated into palisade and spongy parenchyma layer but those varied from species to species. Among the studied species, epidermal circumference found rounded for P. amarus, P. reticulatus, P. acidus, called rings and farrows were observed in cortex. In consideration of hypodermis, most of the species found rectangular except $P$. vigratus had a thick oval shape hypodermis composed of 3-6 layers. Structure of the studied species cortex had a wide range of variations. P. amarus, P. niruri, 
334 a sub-oval shaped cortex, elliptical for $P$. vigratus and rectangular for $P$. debilis. All the species

335 found a moderately thick layered parenchyma composed of 1-15 layer parenchyma or spongy

336 parenchyma cells. $P$. acidus had the thickest layer of parenchyma cells which was 8-15 layered

337 thick (9 A). For all of the studied species, phloem section was thicker than xylem. P. acidus had

338 the thickest layer of phloem cells which was composed of 5-15 layers (table 4, Fig 10).

339 Table 4: Anatomical comparison of stem cross section among studied Phyllanthus.

\section{Discussion}

341 In Bangladesh, very limited works were found that addressing to identify Phyllanthus sp. Ahamed

342 et al. (2008) reported 11 species representing Phyllanthus genus in Bangladesh including 5 herbs,

3434 shrubs and 2 trees. This study found 5 herbs, 1 shrubs and 2 trees in the study area including two

344 new species (Phyllanthus debilis and Phyllanthus amarus) for Bangladeshi flora. Besides

345 application of anatomical features along with taxonomic notes improve the identification of

346 species (Kandavel et al. 2011).

347 Among listed five Phyllanthus herbs, $P$. urinaria and $P$. virgatus were easy to differentiate than

348 others, based on morphological and anatomical features. With rough fruit surface for P. urinaria

349 and long fruit petiole for $P$. virgatus, they were conveniently identifiable in field surveys. $P$.

350 amarus, $P$. debilis and $P$. niruri were morphologically very close and difficult to differentiate.

351 With five calyx segments $P$. amarus was different than $P$. niruri and $P$. debilis with six calyx

352 segments. In the current study, filament stricture found most convenient option to differentiate

353 among them $P$. niruri observed completely connate and joined filaments but for $P$. debilis they

354 were connate at base but free at apex (table 3). In terms of anatomy, P. amarus have rounded

355 epidermal circumference but $P$. niruri and $P$. debilis had angular epidermal circumference. 
Hypodermis layer found key features for differentiate among P. niruri and $P$. debilis. More than 3

357

358

359

360

361

362

363

364

365

366

367

368

369

370

371

372

373

374

375

376

377

378

layered rectangular cell $P$. debilis Hypodermis was different than $P$. niruri, which has less than or exact 3 layered rectangular hypodermis (table 4; Fig 10).

Both Phyllanthus debilis and Phyllanthus amarus were first recorded from India by J. D. Hooker (1890) from North-west India, Sikkim, Bhutan, Hazaribag, Behar and Assam (Hooker, 1890). Prain (1904) also recorded them from Orissa, Chota Nagpur, Behar, Trihut and North Bengal (Prain 1904). In recent days these species were listed in Chennai, Tamil Nadu; Great Nicobar (Srirama et al. 2012). However, they were absent in all regional floristic works of Bangladesh (Rahman \& Jamila 2016; Kona \& Rahman 2015; Rahman et al. 2015; Rahman et al. 2014; Rahman 2013; Rahman \& Akter 2013; Rahman et al. 2013; Uddin \& Hassan 2012; Uddin et al. 2013; Arefin et al. 2011; Uddin \& Hassan 2010; Tutul et al. 2010; Islam et al. 2009; Ahamed et al. 2008; Hossain et al. 2005; Khan \& Huq 2001; Mia \& Khan 1995; Datta \& Mitra 1953). These facts, ensure that this two species were new to the floral database of Bangladesh. This finding will help the path of ecological study of this species for their conservation in Bangladesh.

A specimen Phyllanthus debilis J. G. Klein ex Willd.a was collected from Khulna University Campus ((2248'01.89"N; 89³2'04.60"E) in late October 2015. This species was found in a builtup habitat of Khulna University Nursery and was associated with Phyllanthus niruri L., Hedyotis corymbosa (L.) Lam., Cynodon dactylon (L.) Pers., Cyperus rotundus L., Synedrella nodiflora (L.) Gaertn., Scoparia dulcis L., Lindernia crustacea (L.) F. Muell., Imperata cylindrical (L.) Raeusch, Euphorbia hirta L. and others. Specimen of Phyllanthus amarus Schumach. \& Thonn. was collected from Jessore city area $\left(23^{\circ} 09^{\prime} 55.97 " \mathrm{~N} ; 8^{\circ} 12^{\prime} 15.27^{\prime \prime} \mathrm{E}\right)$ in late April of 2017. It was in association with Synedrella nodiflora (L.) Gaertn., Scoparia dulcis L., Phyllanthus niruri L., Hedyotis corymbosa (L.) Lam., Cyperus rotundus L., Lindernia crustacea (L.) F. Muell., 
Euphorbia thymifolia L., Euphorbia microphylla Lam. Both specimens were identified with key provided by Hooker (1890), Prain (1904) and Wurdack et al. (2004).

\section{References}

1. Ahamed, Z., Hasan, M., Begum, Z., Khondker, M., Kabir, S., Ahamed \& E. Haque (2008). Encyclopedia of Flora and Fauna of Bangladesh, Vol. 6. Angiosperms:

Dicotyledons (Balsaminaceae-Euphorbiaceae). Asiatic Society of Bangladesh, Dhaka, 6, 463-472p.

2. Ali, H., P.J. Houghton \& A. Soumyanath (2006). $\alpha$-Amylase inhibitory activity of some Malaysian plants used to treat diabetes; with particular reference to Phyllanthus amarus. Journal of Ethnopharmacology 107(3): 449-455. https://doi.org/10.1016/j.jep.2006.04.004

3. Arefin, M. K., Rahman, M. M., M.Z. Uddin \& M.A. Hassan (2011). Angiosperm flora of Satchari National Park, Habiganj. Bangladesh. Bangladesh Journal of Plant Taxonomy 18(2): 117-140.

4. Bangladesh Bureau of Statistics (2014). District Statistics 2011 Khulna. Bangladesh Bureau of Statistics, Statistics Division, Dhaka, Bangladesh, 128pp.

5. Calixto, J.B., Santos, A.R., V.C. Filho \& R.A. Yunes (1998). A review of the plants of the genus Phyllanthus: their chemistry, pharmacology, and therapeutic potential. Medicinal Research Reviews 18(4): 225-258.

6. Cesari, I., Grisoli, P., Paolillo, M., Milanese, C., G. Massolini \& G. Brusotti (2015). Isolation and characterization of the alkaloid Nitidine responsible for the traditional use of Phyllanthus muellerianus (Kuntze) Excell stem bark against bacterial infections. 
Journal of Pharmaceutical and Biomedical Analysis 105: 115-120. https://doi.org/10.1016/j.jpba.2014.11.051

7. Datta, R. \& J. Mitra (1953). Common plants in and around Dacca city. Bulletin of the Botanical Society of Bengal 7(1, 2): 1-110. Publishers, New Delhi. 601p. (2003). U.S. Patent No. 6,586,015. Washington, DC: U.S. Patent and Trademark Office.

10. Hoffmann, P., H. Kathriarachchi \& K.J. Wurdack (2006). A phylogenetic classification of Phyllanthaceae (Malpighiales; Euphorbiaceae sensu lato). Kew Bulletin 61 (1): 37-53.

11. Hooker, J. (1890). Flora of British India, Vol. 5. L Reeve and Co., Henrietta Street, Covent Garden, London. 1143 p.

12. Hossain, M.M., M.A. Hassan \& M.Z. Uddin (2005). A checklist of angiospermic flora of Lalmai Hills, Comilla, Bangladesh. Bangladesh Journal of Plant Taxonomy 12(2): 8596.

13. Hyland, B.P. (1972). A technique for collecting botanical specimens in rain forest. Flora Malesiana Bulletin 26(1): 2038-2040.

14. Islam, M.R., M.Z. Uddin \& M.A. Hassan (2009). An assessment of the angiospermic flora of Ramgarh upazila of Khagrachhari district, Bangladesh. Bangladesh Journal of Plant Taxonomy 16(2): 115-140.

15. Islam, M.R., Uddin, M.Z. \& M.A. Hassan (2009). An assessment of the angiospermic flora of Ramgarh upazila of Khagrachhari district, Bangladesh. Bangladesh Journal of Plant Taxonomy 16(2): 115-140. 
16. Kandavel, D., Rani, S.K., M.G. Vinithra \& S. Sekar (2011). Systematic studies in herbaceous Phyllanthus spp. (region: Tiruchirappalli district in India) and a simple key to authenticate 'Bhumyamalaki'complex members. Journal of Phytology 3(2): 37-48.

17. Kanjilal, U.N., P.C. Kanjilal \& A. Das (1938). Flora of Assam, Vol. 2. A Von Book Company, Delhi. 409 p.

18. Khan, M. \& A. Huq (2001). The vascular flora of Chunati wildlife sanctuary in south Chittagong, Bangladesh. Bangladesh Journal of Plant Taxonomy 8(1): 47-64.

19. Kona, S., \& A.M. Rahman (2015). An Assessment of Angiosperm Diversity at Mahadebpur Upazila of Naogaon District, Bangladesh. International Journal of Advanced Research 3(10): 1067-1086.

20. Matthew, K. M. (1999). The flora of the Palni Hills, South India. The Rapinat Herbarium Tiruchirapalli, India. 1880p.

21. Mia, M. \& B. Khan (1995). First list of angiospermic taxa of Bangladesh not included in Hooker's Flora of British India and Prain's Bengal Plants. Bangladesh Journal of Plant Taxonomy 2(1-2): 25-45.

22. Milchunas, D.G., W.K. Lauenroth \& P.L. Chapman (1992). Plant competition, abiotic, and long-and short-term effects of large herbivores on demography of opportunistic species in a semiarid grassland. Oecologia 92(4): 520-531.

23. Okafor, P., Ikpi, M.E., Uwah, I., Ebenso, E., U. Ekpe \& S. Umoren (2008). Inhibitory action of Phyllanthus amarus extracts on the corrosion of mild steel in acidic media. Corrosion Science 50(8): 2310-2317. 
24. Patel, J.R., Tripathi, P., Sharma, V., N.S. Chauhan \& V.K. Dixit (2011). Phyllanthus amarus: ethnomedicinal uses, phytochemistry and pharmacology: a review. Journal of Ethnopharmacology 138(2): 286-313.

25. Prain, D. (1904). Bengal Plants, Vol. 2. Botanical Survey of India, Calcutta, India. 894p.

26. Rahman, A.M. \& M. Akter (2013). Taxonomy and Medicinal Uses of Euphorbiaceae (Spurge) Family of Rajshahi, Bangladesh. Research in Plant Sciences 1(3): 74-80.

27. Rahman, A.M. \& M. Jamila (2016). Angiosperm Diversity at Jamtala Village of Chapai Nawabganj District, Bangladesh with Emphasis on Medicinal Plants. Research in Plant Sciences 4(1): 1-9.

28. Rahman, A.M. (2013). Assessment of Angiosperm Weeds of Rajshahi, Bangladesh with emphasis on medicinal plants. Research in Plant Sciences 1(3): 62-67.

29. Rahman, A.M., Z. Ferdows \& A.R. Islam (2014). A Preliminary Assessment of Angiosperm Flora of Bangladesh Police Academy. Research in Plant Sciences 2(1): 915.

30. Rahman, M.O., M. Begum \& M.V. Ullah (2013). Angiosperm flora of sadar upazila of Munshiganj district, Bangladesh. Bangladesh Journal of Plant Taxonomy 20(2): 213-231.

31. Rahman, M.S., Hossain, G.M., S.A. Khan \& S.N. Uddin (2015). An annotated checklist of the vascular plants of Sundarban Mangrove Forest of Bangladesh. Bangladesh Journal of Plant Taxonomy 22(1): 17-41.

32. Samuel, R., Kathriarachchi, H., Hoffmann, P., Barfuss, M. H., Wurdack, K. J., C.C. Davis \& M.W. Chase (2005). Molecular phylogenetics of Phyllanthaceae: evidence from plastid matK and nuclear PHYC sequences. American Journal of Botany 92(1): 132-141. 
33. Sarin, B., Verma, N., J.P. Martín \& A. Mohanty (2014). An Overview of Important Ethnomedicinal Herbs of Phyllanthus Species: Present Status and Future Prospects. The Scientific World Journal, 2014, 12p. https://doi.org/10.1155/2014/839172

470

471

472

473

474

475

476

477

478

479

480
34. Savolainen, V., Chase, M.W., Hoot, S.B., Morton, C.M., Soltis, D.E., C. Bayer \& Y.L. Qiu (2000). Phylogenetics of flowering plants based on combined analysis of plastid atpB and rbcL gene sequences. Systematic Biology 49(2): 306-362.

35. Srirama, R., Deepak, H.B., Senthilkumar, U., Ravikanth, G., Gurumurthy, B.R., M.B. Shivanna \& R.U. Shaanker (2012). Hepatoprotective activity of Indian Phyllanthus. Pharmaceutical Biology 50(8): 948-953. https://doi.org/10.3109/13880209.2011.649858

36. Thyagarajan, S., Thirunalasundari, T., Subramanian, S., P. Venkateswaran \& B. Blumberg (1988). Effect of Phyllanthus amarus on chronic carriers of hepatitis B virus. The Lancet 332(8614): 764-766. https://doi.org/10.1016/S0140-6736(88)92416-6

37. Tutul, E., Uddin, M. Z., M.O. Rahman \& M.A. Hassan (2010). Angiospermic flora of runctia sal forest, Bangladesh. ii. magnoliopsida (dicots). Bangladesh Journal of Plant Taxonomy 17(1): 33-53.

38. Uddin, M.Z \& M.A. Hassan (2010). Angiosperm diversity of Lawachara National Park (Bangladesh): a preliminary assessment. Bangladesh Journal of Plant Taxonomy 17(1): 9-22.

39. Uddin, M.Z., Alam, M.F., M.A. Rhaman \& M.A. Hassan (2013). Diversity in angiosperm flora of Teknaf wildlife sanctuary, Bangladesh. Bangladesh Journal of Plant Taxonomy 20(2): 145-162. 
40. Uddin, S.N. \& M.A. Hassan (2012). Angiosperm flora of Rampahar reserve forest under Rangamati district in Bangladesh. I. Liliopsida (Monocots). Bangladesh Journal of Plant Taxonomy 19(1): 37-44

41. Webster, G.L. (1956). A monographic study of the West Indian species of Phyllanthus. Journal of the Arnold Arboretum 37(3): 217-268.

42. Wurdack, K. J., Hoffmann, P., Samuel, R., de Bruijn, A., M. van der Bank \& M.W. Chase (2004). Molecular phylogenetic analysis of Phyllanthaceae (Phyllanthoideae pro parte, Euphorbiaceae sensu lato) using plastid rbcL DNA sequences. American Journal of Botany 91(11): 1882-1900.

Acknowledgements: Authors are thankful to Prof. A.K. Fazlul Hoque for his comments on the initial version of the manuscript. They also acknowledge Prof. Dr. Iftekhar Shams for lab support and encouragement for this study. 
Fig.2- Fig. 10

$501 \quad$ Figures and table option

502 Fig 1: Map of the study area

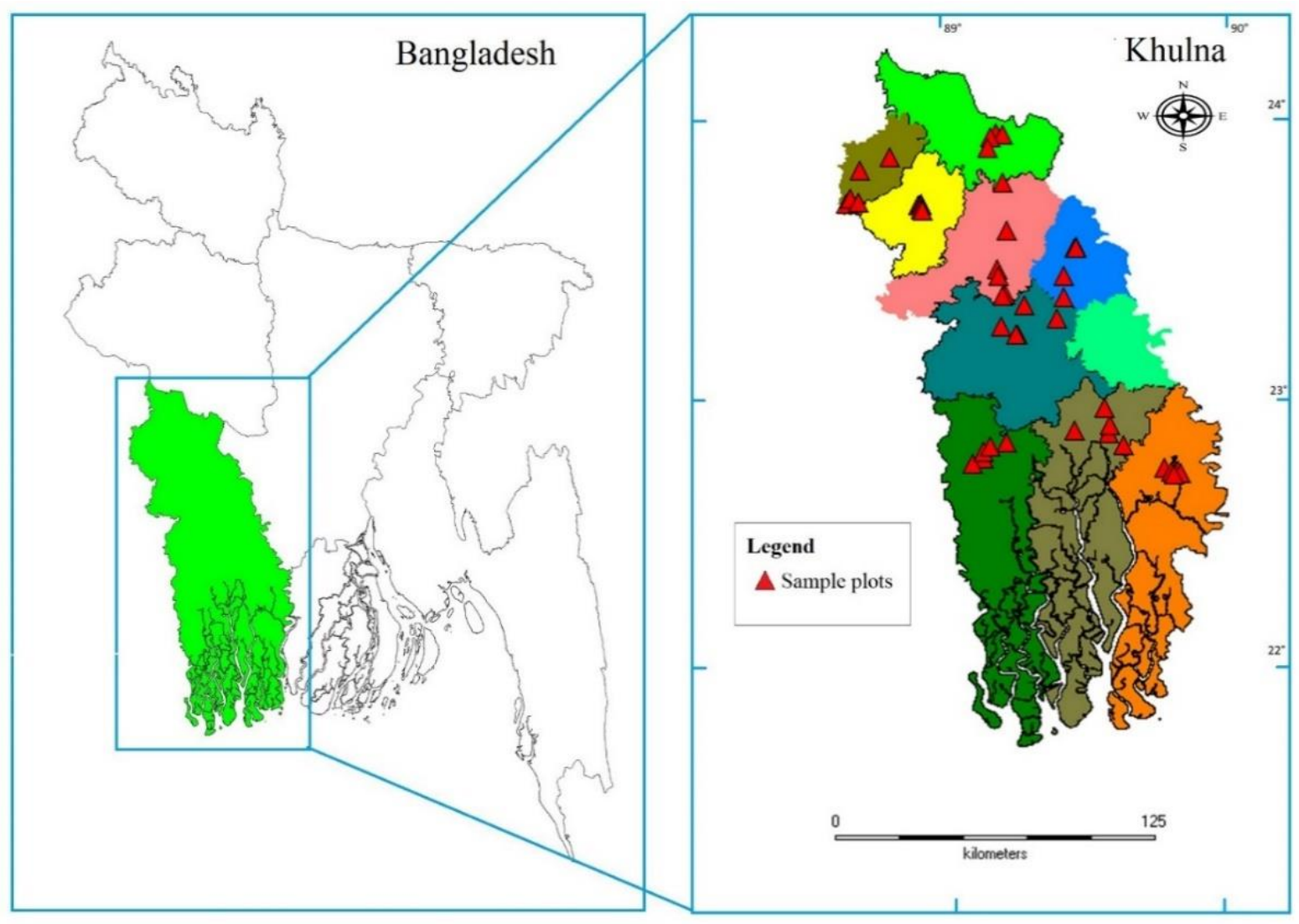


bioRxiv preprint doi: https://doi.org/10.1101/608711; this version posted April 13, 2019. The copyright holder for this preprint (which was not certified by peer review) is the author/funder. All rights reserved. No reuse allowed without permission.

504 Fig. 2: Different parts of Phyllanthus acidus (L.) Skeels

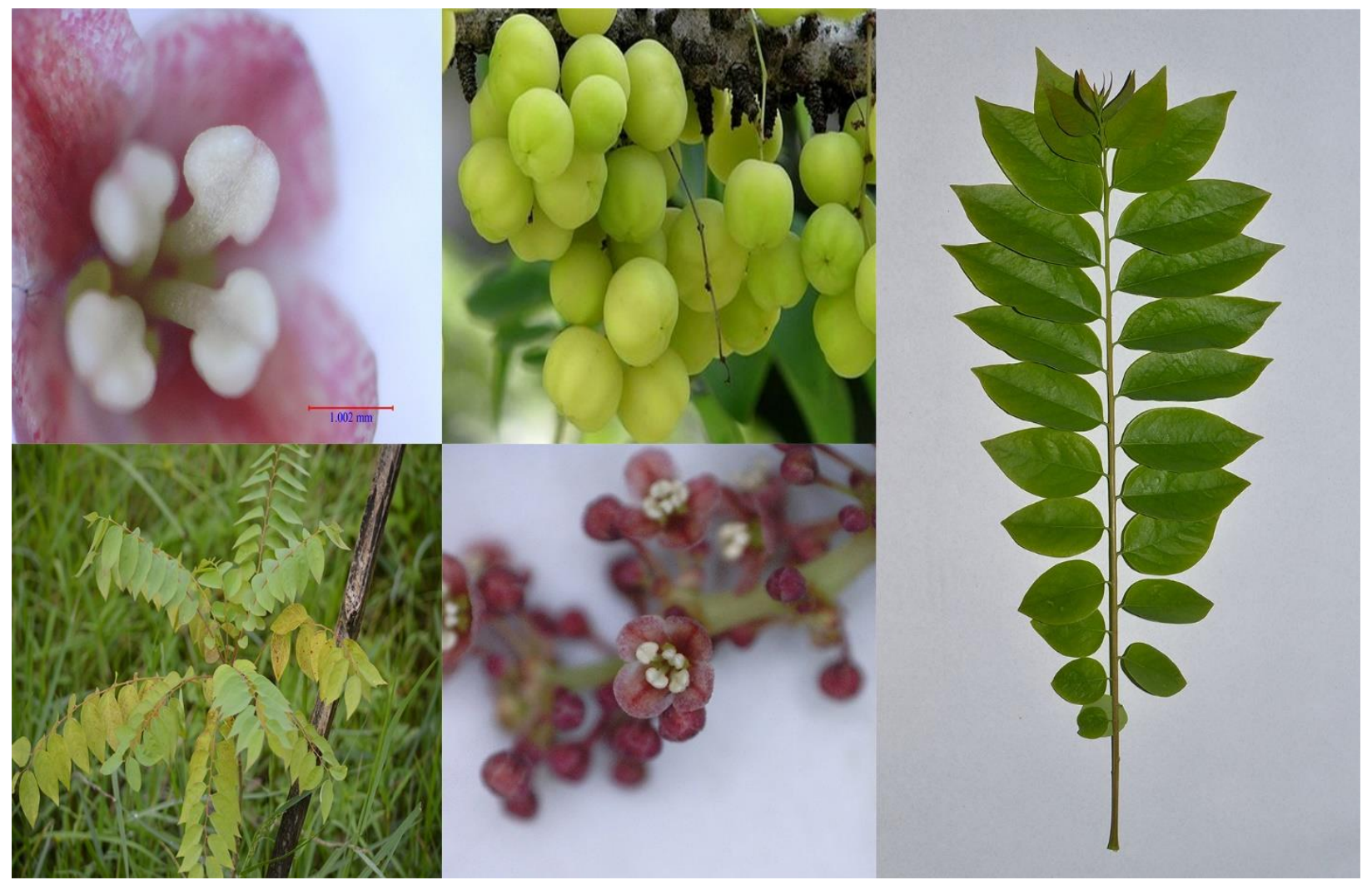

506 Fig. 3: Different parts of Phyllanthus amarus Schumach. \& Thonn 

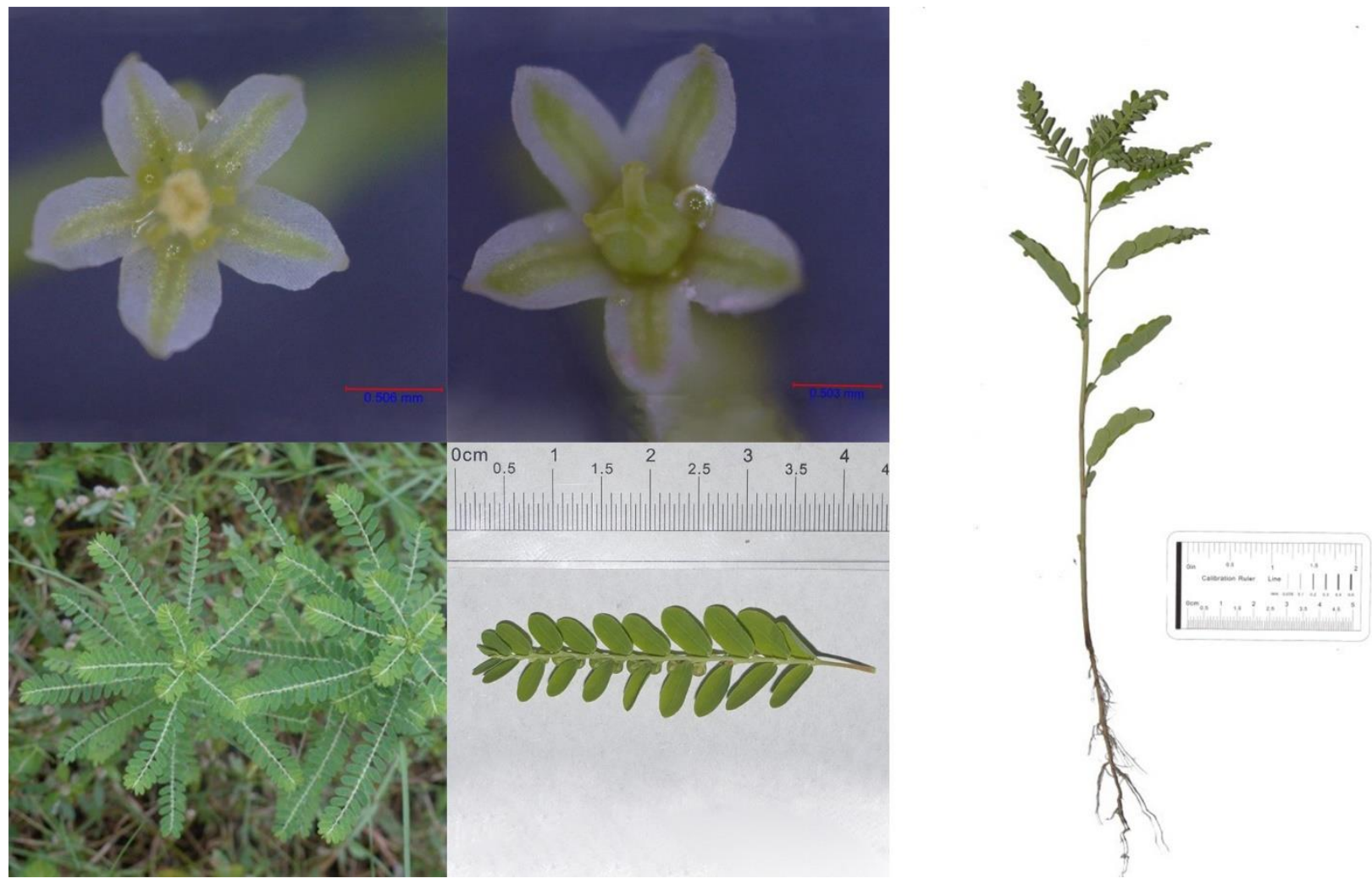

Fig. 4: Different parts of Phyllanthus debilis J.G.Klein ex Willd.
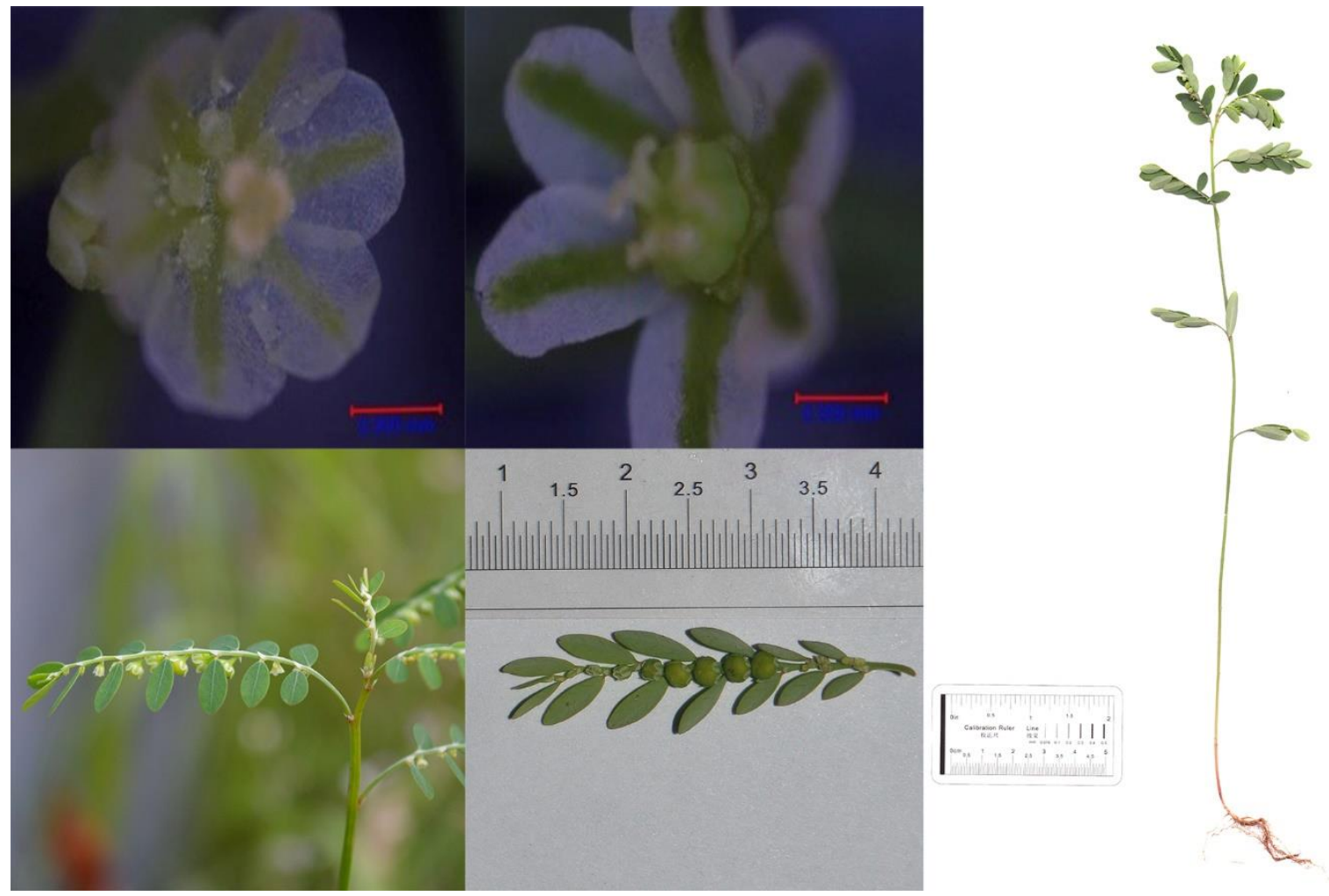
bioRxiv preprint doi: https://doi.org/10.1101/608711; this version posted April 13, 2019. The copyright holder for this preprint (which was not certified by peer review) is the author/funder. All rights reserved. No reuse allowed without permission.

510 Fig. 5: Different parts of Phyllanthus emblica L.

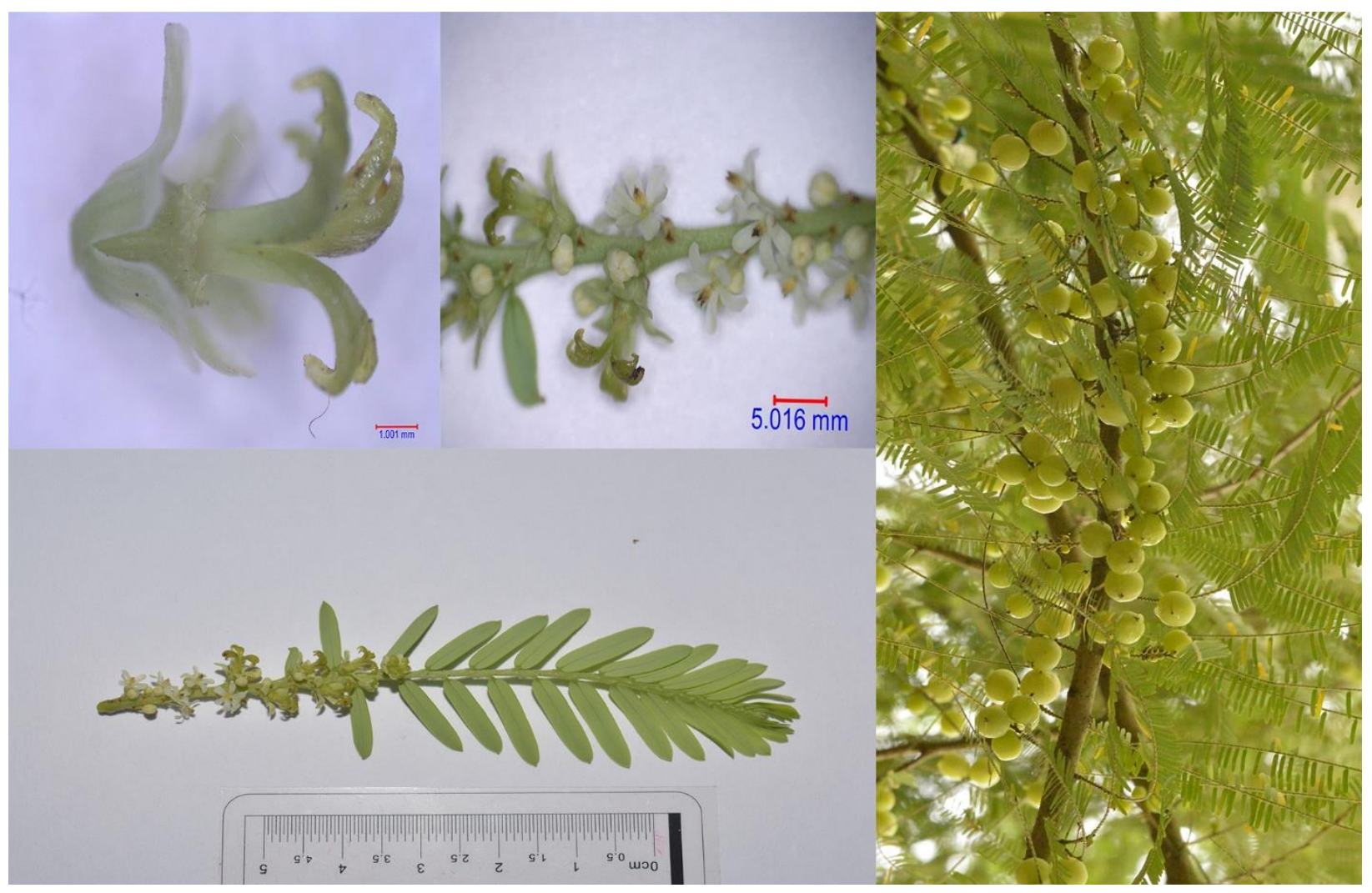

512 Fig. 6: Different parts of Phyllanthus niruri L. 
bioRxiv preprint doi: https://doi.org/10.1101/608711; this version posted April 13, 2019. The copyright holder for this preprint (which was not certified by peer review) is the author/funder. All rights reserved. No reuse allowed without permission.
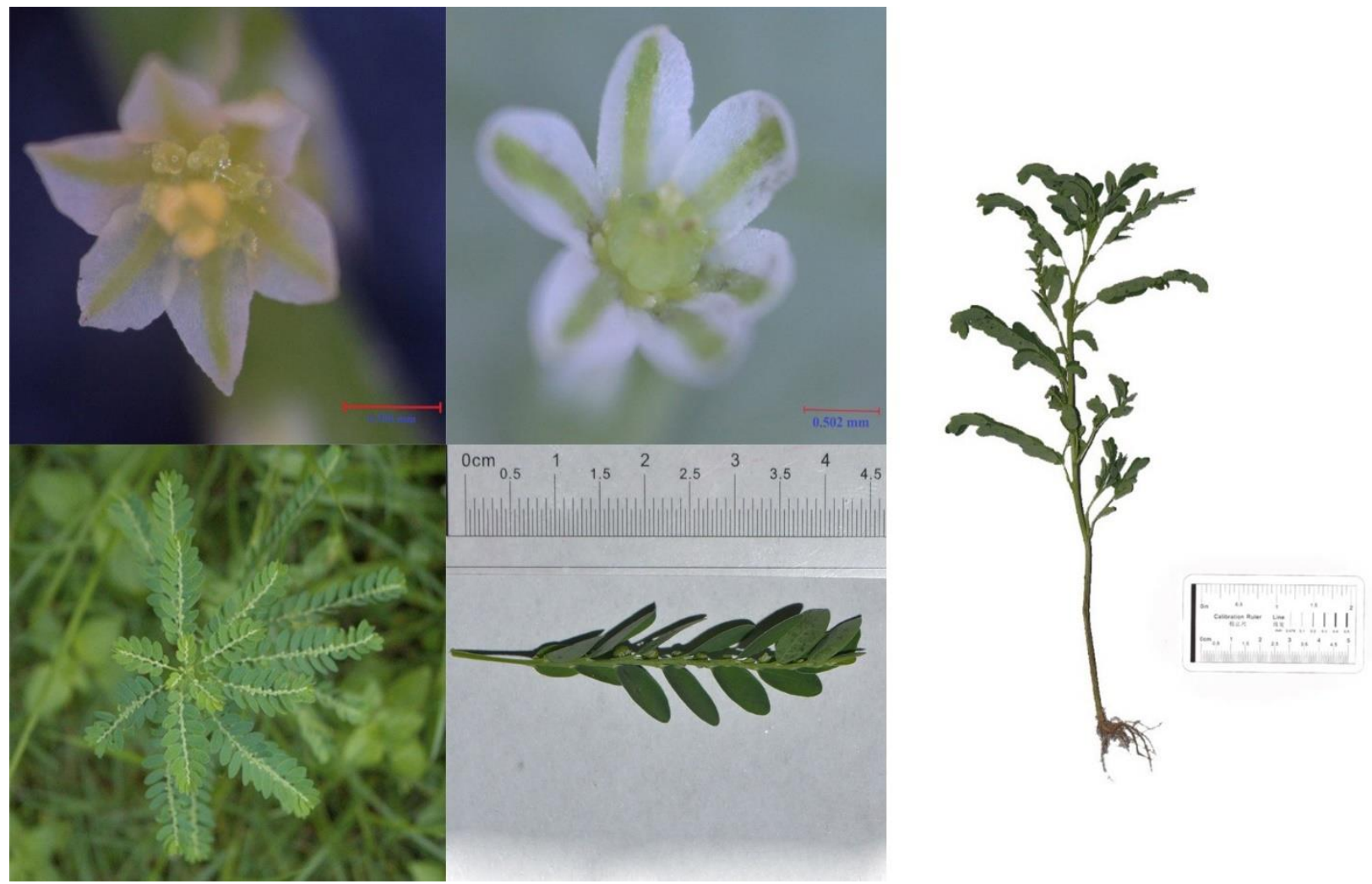

$514 \quad$ Fig. 7: Different parts of Phyllanthus reticulatus Poir.

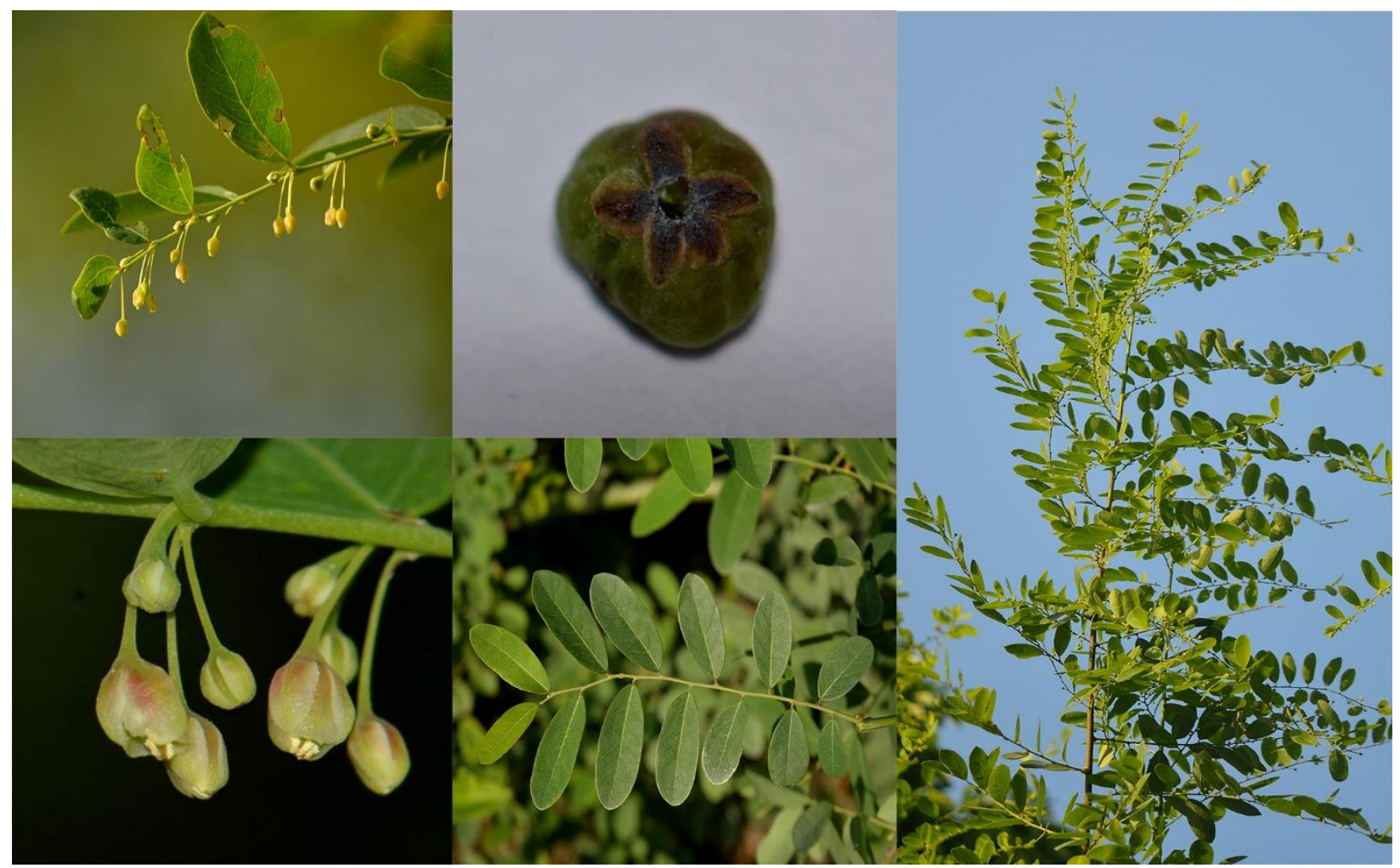


bioRxiv preprint doi: https://doi.org/10.1101/608711; this version posted April 13, 2019. The copyright holder for this preprint (which was not certified by peer review) is the author/funder. All rights reserved. No reuse allowed without permission.

Fig. 8: Different parts of Phyllanthus urinaria L.
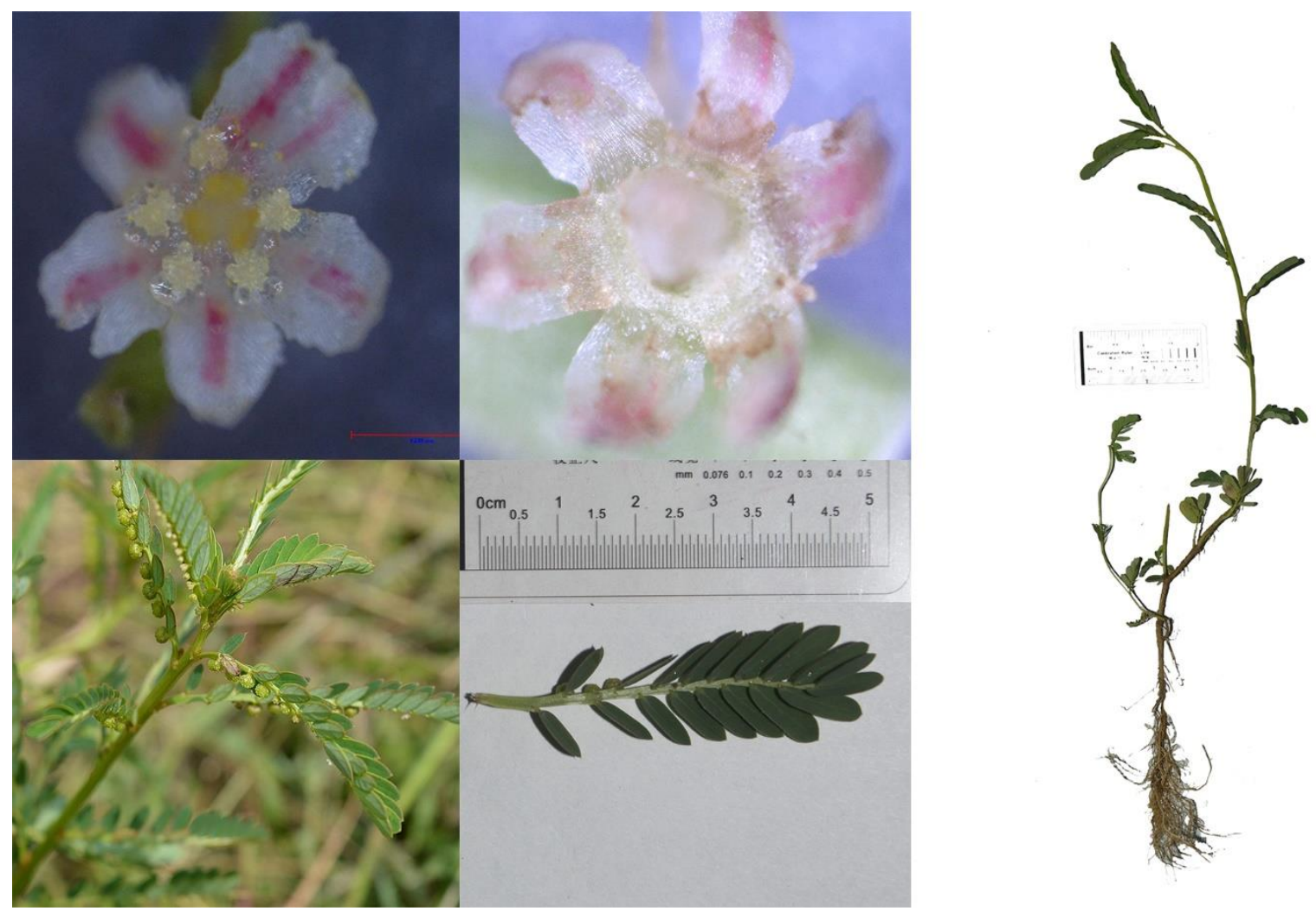

518 Fig 9: Different parts of Phyllanthus virgatus G.Forst. 

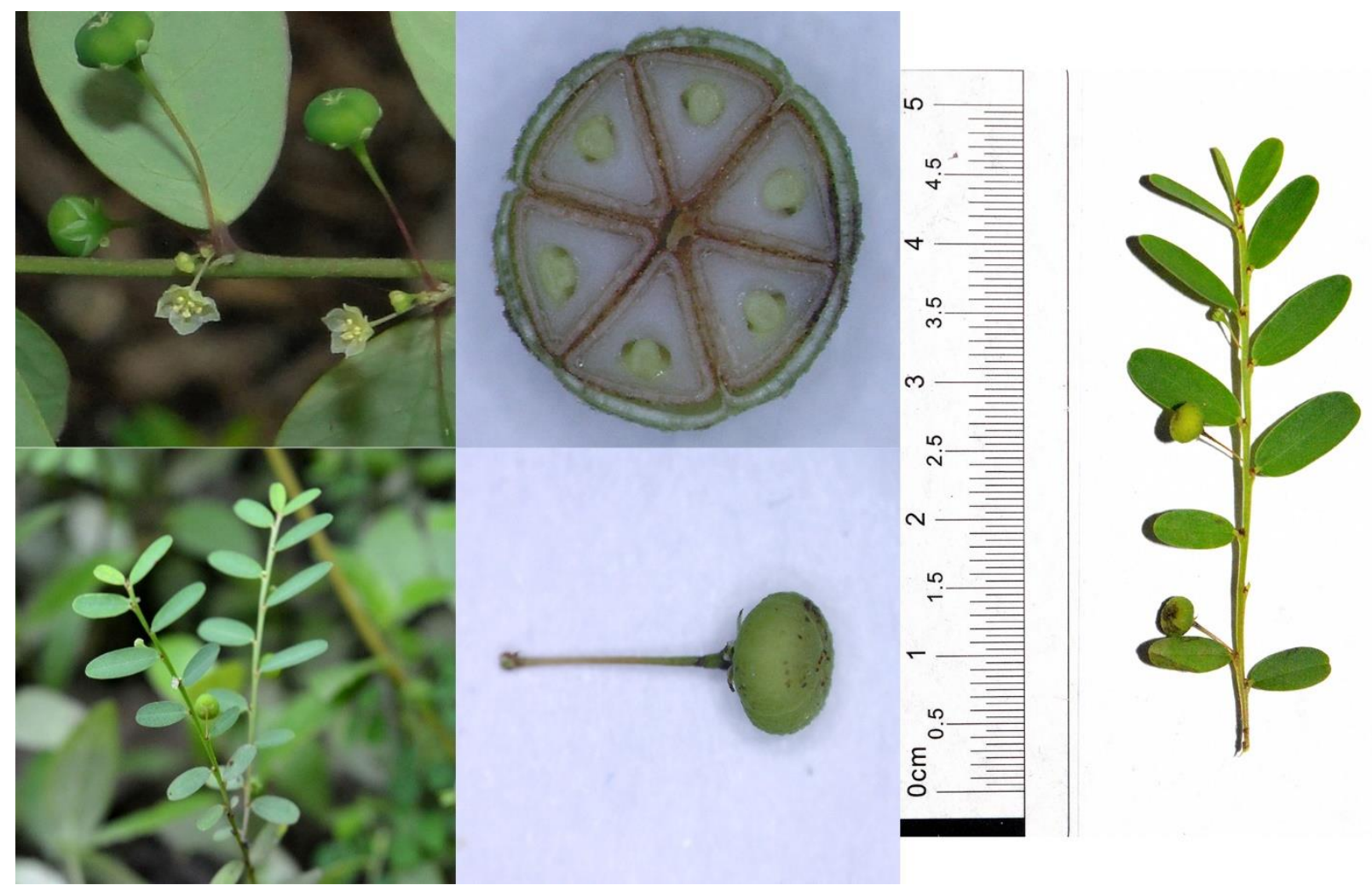

520 Fig 10: Cross section of stem of phyllanthus of southwestern Bangladesh. (a: P. acidus, b: $P$.

521 amarus, c: P. debilis d: P. emblica, e: P. niruri, f: P. reticulatus, g: P. urinaria, h: P. vigratus) 
bioRxiv preprint doi: https://doi.org/10.1101/608711; this version posted April 13, 2019. The copyright holder for this preprint (which was not certified by peer review) is the author/funder. All rights reserved. No reuse allowed without permission.
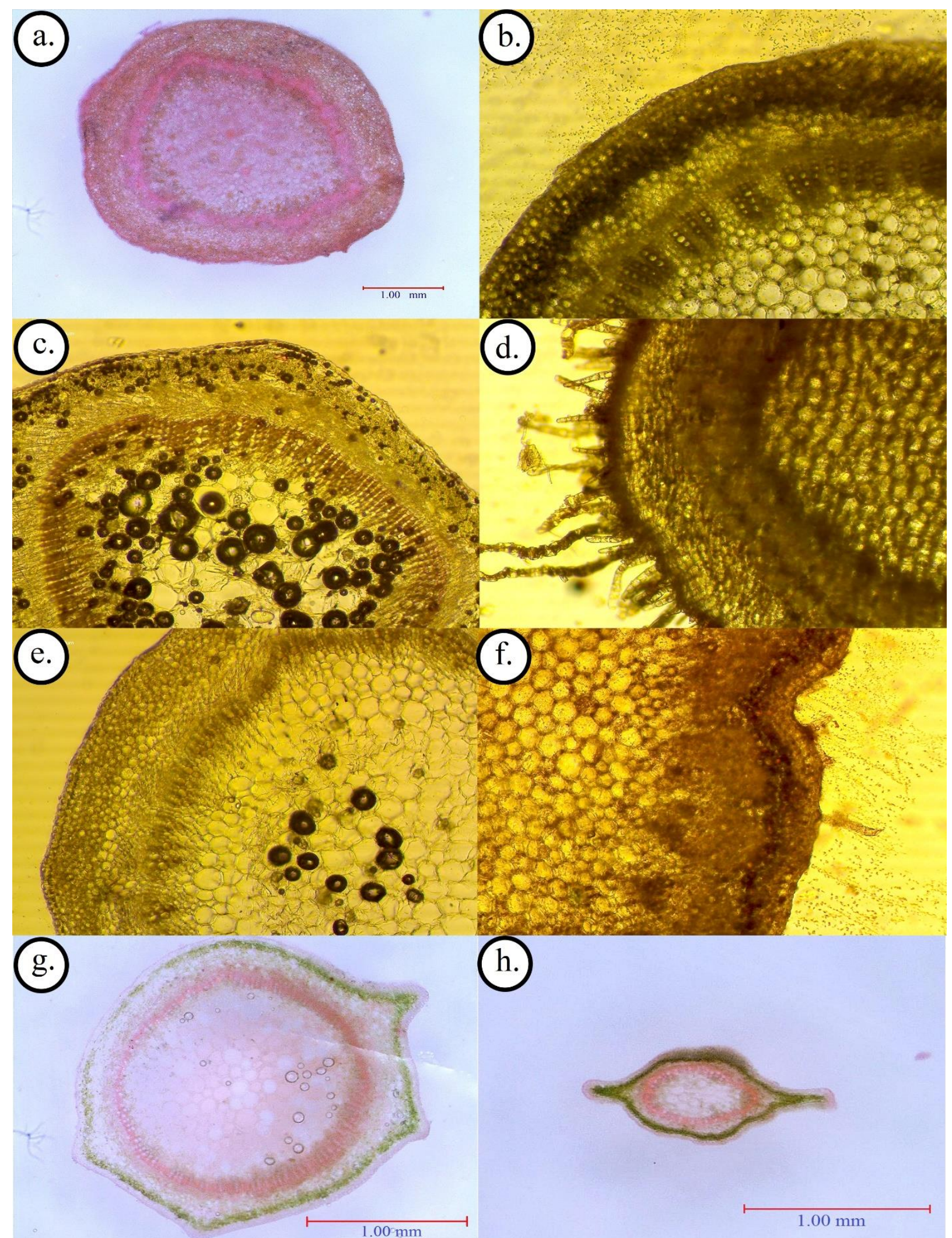

(h.)
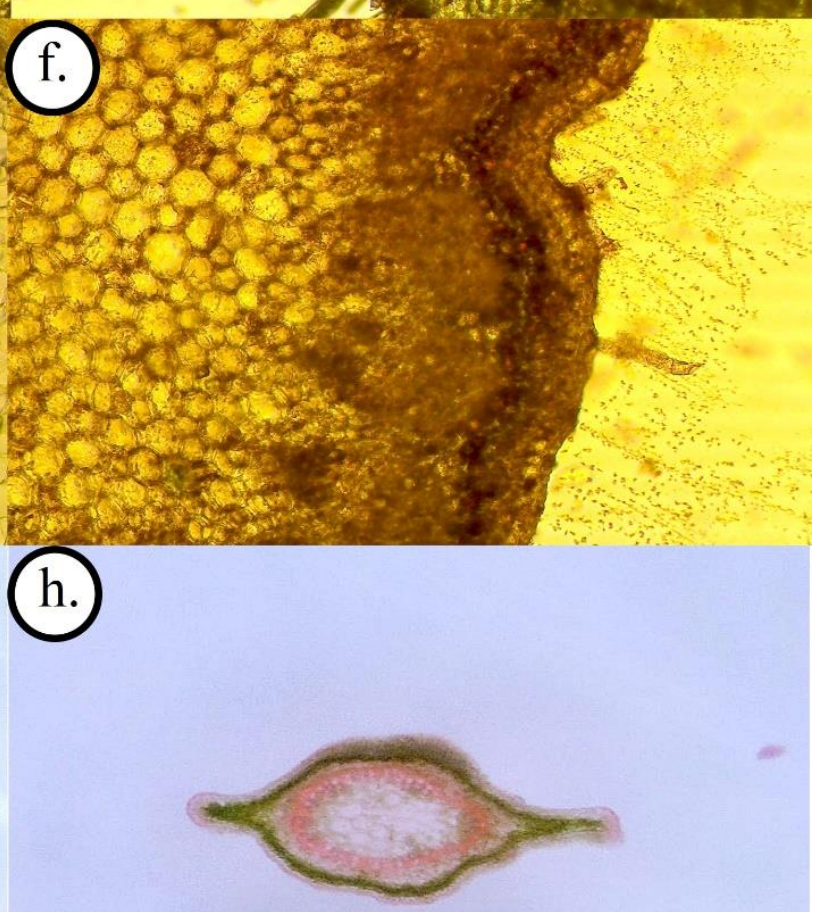

$1.00 \mathrm{~mm}$ 
523 Table 1: A list of locations in the southwestern region of Bangladesh surveyed during the study

524 period

\begin{tabular}{|c|c|c|c|c|c|c|}
\hline $\begin{array}{l}\text { Sl } \\
\text { no. }\end{array}$ & District & Place & Latitude & Longitude & $\begin{array}{l}\text { No. of } \\
\text { individuals }\end{array}$ & $\begin{array}{l}\text { No. of } \\
\text { species }\end{array}$ \\
\hline 1. & Khulna & KU Campus & $22.80125^{\circ} \mathrm{N}$ & $89.53466^{\circ} \mathrm{E}$ & 117 & 6 \\
\hline 2. & & Boyra & $22.83289^{\circ} \mathrm{N}$ & $89.54131^{\circ} \mathrm{E}$ & 46 & 5 \\
\hline 3. & & Dumuria & $22.80936^{\circ} \mathrm{N}$ & $89.41360^{\circ} \mathrm{E}$ & 67 & 5 \\
\hline 4. & & Dhigholia & $22.89416^{\circ} \mathrm{N}$ & $89.52221^{\circ} \mathrm{E}$ & 32 & 4 \\
\hline 5. & & Baintala & $22.75812^{\circ} \mathrm{N}$ & $89.58919^{\circ} \mathrm{E}$ & 13 & 3 \\
\hline 6. & Jessore & Pouro park & $23.16508^{\circ} \mathrm{N}$ & $89.20466^{\circ} \mathrm{E}$ & 41 & 4 \\
\hline 7. & & M. M. collage & $23.16234^{\circ} \mathrm{N}$ & $89.20328^{\circ} \mathrm{E}$ & 33 & 4 \\
\hline 8. & & Cantonment & $23.19148^{\circ} \mathrm{N}$ & $89.14975^{\circ} \mathrm{E}$ & 41 & 6 \\
\hline 9. & & Labutala & $23.27200^{\circ} \mathrm{N}$ & $89.23148^{\circ} \mathrm{E}$ & 49 & 6 \\
\hline 10. & & Bagherpara & $23.22126^{\circ} \mathrm{N}$ & $89.34825^{\circ} \mathrm{E}$ & 11 & 4 \\
\hline 11. & Satkhira & Govet. collage & $22.71028^{\circ} \mathrm{N}$ & $89.08503^{\circ} \mathrm{E}$ & 23 & 5 \\
\hline 12. & & Medical collage & $22.69100^{\circ} \mathrm{N}$ & $89.04764^{\circ} \mathrm{E}$ & 41 & 5 \\
\hline 13. & & BGB camp & $22.73244^{\circ} \mathrm{N}$ & $89.08453^{\circ} \mathrm{E}$ & 78 & 5 \\
\hline 14. & & Binerpota & $22.75447^{\circ} \mathrm{N}$ & $89.10717^{\circ} \mathrm{E}$ & 47 & 4 \\
\hline 15. & & Patkelgatha & $22.76752^{\circ} \mathrm{N}$ & $89.16900^{\circ} \mathrm{E}$ & 39 & 4 \\
\hline 16. & Bhagerhat & $\begin{array}{l}\text { Satgomuj } \\
\text { Mosque }\end{array}$ & $22.67461^{\circ} \mathrm{N}$ & $89.73788^{\circ} \mathrm{E}$ & 71 & 4 \\
\hline
\end{tabular}




\begin{tabular}{|c|c|c|c|c|c|c|}
\hline 17. & & $\begin{array}{l}\text { Khanjahan Ali } \\
\text { Majar }\end{array}$ & $22.66067^{\circ} \mathrm{N}$ & $89.76032^{\circ} \mathrm{E}$ & 23 & 3 \\
\hline 18. & & PC College & $22.66543^{\circ} \mathrm{N}$ & $89.78261^{\circ} \mathrm{E}$ & 87 & 6 \\
\hline 19. & & Pouro Lake & $22.65560^{\circ} \mathrm{N}$ & $89.79535^{\circ} \mathrm{E}$ & 21 & 4 \\
\hline 20. & & Pocha Dighi & $22.64870^{\circ} \mathrm{N}$ & $89.77262^{\circ} \mathrm{E}$ & 23 & 5 \\
\hline 21. & Magura & $\begin{array}{l}\text { Govt. HSS } \\
\text { College }\end{array}$ & $23.48938^{\circ} \mathrm{N}$ & $89.41914^{\circ} \mathrm{E}$ & 19 & 3 \\
\hline 22. & & Stadium Para & $23.48232^{\circ} \mathrm{N}$ & $89.41420^{\circ} \mathrm{E}$ & 40 & 4 \\
\hline 23. & & $\begin{array}{l}\text { District Fishery } \\
\text { Office }\end{array}$ & $23.48080^{\circ} \mathrm{N}$ & $89.41904^{\circ} \mathrm{E}$ & 47 & 5 \\
\hline 24. & & Arpara & $23.37775^{\circ} \mathrm{N}$ & $89.37197^{\circ} \mathrm{E}$ & 38 & 5 \\
\hline 25. & & Salikha & $23.30223^{\circ} \mathrm{N}$ & $89.37575^{\circ} \mathrm{E}$ & 112 & 6 \\
\hline 26. & Jhinaidha & KC College & $23.54539^{\circ} \mathrm{N}$ & $89.17012^{\circ} \mathrm{E}$ & 13 & 2 \\
\hline 27. & & Kaligang & $23.40495^{\circ} \mathrm{N}$ & $89.13213^{\circ} \mathrm{E}$ & 35 & 4 \\
\hline 28. & & Dulal-Mundia & $23.38004^{\circ} \mathrm{N}$ & $89.13924^{\circ} \mathrm{E}$ & 72 & 5 \\
\hline 29. & & $\begin{array}{l}\text { Gazi-Kalu } \\
\text { Mazar }\end{array}$ & $23.30836^{\circ} \mathrm{N}$ & $89.16321^{\circ} \mathrm{E}$ & 67 & 6 \\
\hline 30. & & $\begin{array}{l}\text { Barobazar } \\
\text { Railway Station }\end{array}$ & $23.30488^{\circ} \mathrm{N}$ & $89.15081^{\circ} \mathrm{E}$ & 93 & 6 \\
\hline 31. & Kushtia & $\begin{array}{l}\text { Kushtia Govt. } \\
\text { College }\end{array}$ & $23.90175^{\circ} \mathrm{N}$ & $89.12837^{\circ} \mathrm{E}$ & 73 & 6 \\
\hline 32. & & Kushtia Soshan & $23.89993^{\circ} \mathrm{N}$ & $89.15211^{\circ} \mathrm{E}$ & 65 & 5 \\
\hline 33. & & Chourhas & $23.88921^{\circ} \mathrm{N}$ & $89.10866^{\circ} \mathrm{E}$ & 34 & 5 \\
\hline
\end{tabular}




\begin{tabular}{|c|c|c|c|c|c|c|}
\hline 34. & & Bot-toil & $23.85114^{\circ} \mathrm{N}$ & $89.09854^{\circ} \mathrm{E}$ & 59 & 5 \\
\hline 35. & & IU Campus & $23.72105^{\circ} \mathrm{N}$ & $89.15204^{\circ} \mathrm{E}$ & 20 & 6 \\
\hline 36. & Chuadanga & $\begin{array}{l}\text { Chuadanga } \\
\text { Govt. College }\end{array}$ & $23.63979^{\circ} \mathrm{N}$ & $88.84907^{\circ} \mathrm{E}$ & 67 & 5 \\
\hline 37. & & Rail Para & $23.64256^{\circ} \mathrm{N}$ & $88.85871^{\circ} \mathrm{E}$ & 17 & 4 \\
\hline 38. & & Bus Terminal & $23.63715^{\circ} \mathrm{N}$ & $88.86063^{\circ} \mathrm{E}$ & 90 & 5 \\
\hline 39. & & Jafarpur & $23.62353^{\circ} \mathrm{N}$ & $88.85984^{\circ} \mathrm{E}$ & 42 & 5 \\
\hline 40. & & BGB Camp & $23.62049^{\circ} \mathrm{N}$ & $88.86415^{\circ} \mathrm{E}$ & 65 & 5 \\
\hline 41. & Meherpur & Mujibnagar & $23.64411^{\circ} \mathrm{N}$ & $88.59134^{\circ} \mathrm{E}$ & 43 & 5 \\
\hline 42. & & Kedergong & $23.66181^{\circ} \mathrm{N}$ & $88.60596^{\circ} \mathrm{E}$ & 34 & 3 \\
\hline 43. & & Bollovpur & $23.64793^{\circ} \mathrm{N}$ & $88.63281^{\circ} \mathrm{E}$ & 51 & 3 \\
\hline 44. & & Collage road & $23.76746^{\circ} \mathrm{N}$ & $88.63974^{\circ} \mathrm{E}$ & 9 & 2 \\
\hline 45. & & Gangni & $23.81729^{\circ} \mathrm{N}$ & $88.74912^{\circ} \mathrm{E}$ & 81 & 5 \\
\hline
\end{tabular}


526 Table 2: List and distribution of the listed Phyllanthus sp. at current study (* new record for

527 Bangladesh).

\begin{tabular}{|c|c|c|c|c|c|c|c|c|}
\hline & $\begin{array}{l}P . \\
\text { acidus }\end{array}$ & $\begin{array}{l}P . \\
\text { amarus* }^{*}\end{array}$ & $\begin{array}{l}P . \\
\text { debilis* }\end{array}$ & $\begin{array}{l}P . \\
\text { emblica }\end{array}$ & $\begin{array}{l}P . \\
\text { niruri }\end{array}$ & $\begin{array}{l}P . \\
\text { reticulatus }\end{array}$ & $\begin{array}{l}P . \\
\text { urinaria }\end{array}$ & $\begin{array}{l}P . \\
\text { virgatus }\end{array}$ \\
\hline Khulna & $\checkmark$ & $\checkmark$ & $\checkmark$ & $\checkmark$ & $\checkmark$ & $\checkmark$ & $\checkmark$ & \\
\hline Jessore & $\checkmark$ & $\checkmark$ & & $\checkmark$ & $\checkmark$ & $\checkmark$ & $\checkmark$ & $\checkmark$ \\
\hline Satkhira & $\checkmark$ & $\checkmark$ & & $\checkmark$ & $\checkmark$ & $\checkmark$ & $\checkmark$ & \\
\hline Bhagerhat & $\checkmark$ & $\checkmark$ & & $\checkmark$ & $\checkmark$ & $\checkmark$ & $\checkmark$ & \\
\hline Magura & $\checkmark$ & $\checkmark$ & & $\checkmark$ & & $\checkmark$ & $\checkmark$ & \\
\hline Jhinaidha & $\checkmark$ & $\checkmark$ & & $\checkmark$ & & $\checkmark$ & $\checkmark$ & $\checkmark$ \\
\hline $\begin{array}{l}\text { Chuadang } \\
\text { a }\end{array}$ & $\checkmark$ & $\checkmark$ & & $\checkmark$ & $\checkmark$ & $\checkmark$ & $\checkmark$ & $\checkmark$ \\
\hline Meherpur & $\checkmark$ & $\checkmark$ & & $\checkmark$ & $\checkmark$ & $\checkmark$ & $\checkmark$ & $\checkmark$ \\
\hline Kushtia & $\checkmark$ & $\checkmark$ & & $\checkmark$ & $\checkmark$ & $\checkmark$ & $\checkmark$ & $\checkmark$ \\
\hline
\end{tabular}


Table 3: Morphological comparisons among studied Phyllanthus.

\begin{tabular}{|c|c|c|c|c|c|c|c|c|}
\hline & P. amarus & P. debilis & P. niruri & P. urinaria & P. virgatus & P. reticulatus & P. acidus & P. emblica \\
\hline Form & Herb & Herb & Herb & Herb & Herb & Shrub & Tree & Tree \\
\hline Branchlets & Present & Present & Present & Present & Absent & Present & Present & Present \\
\hline $\begin{array}{l}\text { Leaf } \\
\text { shape }\end{array}$ & $\begin{array}{l}\text { Oblong or } \\
\text { elliptic- } \\
\text { oblong }\end{array}$ & $\begin{array}{l}\text { Narrowly } \\
\text { elliptic to } \\
\text { lanceolate }\end{array}$ & $\begin{array}{l}\text { Elliptic- } \\
\text { obolong to } \\
\text { elliptic- } \\
\text { oblanceolate }\end{array}$ & $\begin{array}{l}\text { Linear-oblong } \\
\text { to oblong- } \\
\text { obovate }\end{array}$ & $\begin{array}{l}\text { Obolong- } \\
\text { elliptic }\end{array}$ & $\begin{array}{l}\text { Varying but } \\
\text { mostly obtuse } \\
\text { to rounded }\end{array}$ & $\begin{array}{l}\text { Ovate to } \\
\text { ovate- } \\
\text { lanceolate }\end{array}$ & $\begin{array}{l}\text { Oblong or } \\
\text { linear-oblong }\end{array}$ \\
\hline Leaf apex & $\begin{array}{l}\text { Cbtuse or } \\
\text { rounded }\end{array}$ & $\begin{array}{l}\text { Acute to } \\
\text { acuminate }\end{array}$ & $\begin{array}{l}\text { Obtuse or } \\
\text { rounded }\end{array}$ & Acute & $\begin{array}{l}\text { Obtuse or } \\
\text { acuminate }\end{array}$ & $\begin{array}{l}\text { Obtuse to } \\
\text { rounded }\end{array}$ & $\begin{array}{l}\text { Acute to } \\
\text { acuminate }\end{array}$ & Obtuse \\
\hline Leaf base & Rounded & $\begin{array}{l}\text { Cuneate } \\
\text { to acute }\end{array}$ & Tapering & $\begin{array}{l}\text { Mucronulate, } \\
\text { conspicuously } \\
\text { ariculate or } \\
\text { obtuse }\end{array}$ & $\begin{array}{l}\text { prominently } \\
\text { and } \\
\text { asymmetrically } \\
\text { auriculate }\end{array}$ & Cuneate & $\begin{array}{l}\text { Rounded } \\
\text { or broadly } \\
\text { cuneate. }\end{array}$ & $\begin{array}{l}\text { Shallowly } \\
\text { cordate and } \\
\text { slightly } \\
\text { oblique }\end{array}$ \\
\hline $\begin{array}{l}\text { Lateral } \\
\text { vine }\end{array}$ & 4-7 pair & 5-7 pair & 4-7 pair & 4-6 pair & 6-9 pair & 5-9 pair & 5-7 pair & 4-9 pair \\
\hline
\end{tabular}




\begin{tabular}{|c|c|c|c|c|c|c|c|c|}
\hline Sepals & Five & Six & Six & Six & Six & Five & Four & Six \\
\hline $\begin{array}{l}\text { Disk } \\
\text { segments }\end{array}$ & Five & Six & Six & Six & Six & Five & Four & Six \\
\hline Filaments & $\begin{array}{l}\text { Completely } \\
\text { connate }\end{array}$ & $\begin{array}{l}\text { Connate } \\
\text { at base } \\
\text { and free } \\
\text { at apex }\end{array}$ & $\begin{array}{l}\text { Completely } \\
\text { connate }\end{array}$ & $\begin{array}{l}\text { Connate, } \\
\text { united into a } \\
\text { slender } \\
\text { column }\end{array}$ & Connate, Free & Stout & $\begin{array}{l}\text { Kidney } \\
\text { shaped. }\end{array}$ & Stout \\
\hline Style & $\begin{array}{l}\text { Three, } \\
\text { Minutely } \\
\text { bifid at tip. }\end{array}$ & $\begin{array}{l}\text { Three, } \\
\text { Minutely } \\
\text { bifid at } \\
\text { middle. }\end{array}$ & $\begin{array}{l}\text { Three, } \\
\text { triangular } \\
\text { and bifid. }\end{array}$ & $\begin{array}{l}\text { Three, free } \\
\text { and adpressed } \\
\text { to the top of } \\
\text { ovary. }\end{array}$ & $\begin{array}{l}\text { Three, boiled } \\
\text { at apex }\end{array}$ & $\begin{array}{l}\text { Five, two free } \\
\text { and three } \\
\text { united. }\end{array}$ & $\begin{array}{l}\text { Four, free } \\
\text { and two } \\
\text { shorter. }\end{array}$ & Two parted \\
\hline Fruit & Capsule & Capsule & Capsule & Capsule & Capsule & Barry & Drupe & Capsule \\
\hline Calyx & Five lobed & $\begin{array}{l}\text { Six lobed } \\
\text { (apex } \\
\text { rounded) }\end{array}$ & $\begin{array}{l}\text { Six lobed } \\
\text { (apex acute) }\end{array}$ & Six lobed & Six lobed & Five lobed & Six lobed & Six lobed \\
\hline
\end{tabular}


Table 4: Anatomical comparison of stem cross section among studied Phyllanthus.

\begin{tabular}{|c|c|c|c|c|c|c|c|c|}
\hline & P. amarus & P. debilis & P. niruri & P. urinaria & P. virgatus & P. reticulatus & P. acidus & P. emblica \\
\hline $\begin{array}{l}\text { Epidermal } \\
\text { circumference }\end{array}$ & Rounded & Angular & Angular & Angular & Elliptical & Rounded & Rounded & Rounded \\
\hline $\begin{array}{l}\text { Ring and } \\
\text { Farrows }\end{array}$ & Absent & Absent & Absent & Present & Absent & Absent & Absent & Absent \\
\hline Hypodermis & $\begin{array}{l}\text { Rectangular } \\
\text { 2-3 layer } \\
\text { thick }\end{array}$ & $\begin{array}{l}\text { Rectangular } \\
\text { 4-5 layer } \\
\text { thick }\end{array}$ & $\begin{array}{l}\text { Rectangular } \\
\text { 2-3 layer } \\
\text { thick }\end{array}$ & $\begin{array}{l}\text { Rectangular } \\
\text { 2-5 layer } \\
\text { thick }\end{array}$ & $\begin{array}{l}\text { Rectangular } \\
\text { 3-4 layer } \\
\text { thick }\end{array}$ & $\begin{array}{l}\text { Rectangular } \\
\text { 3-5 layer } \\
\text { thick }\end{array}$ & $\begin{array}{l}\text { Rectangu } \\
\text { lar } \\
\text { 2-5 layer } \\
\text { thick }\end{array}$ & $\begin{array}{l}\text { Oval } \\
\text { 3-6 layer thick }\end{array}$ \\
\hline Cortex & Oval & Rectangular & Oval & Oval & Elliptical & Oval & Oval & Sub-oval \\
\hline Parenchyma & $\begin{array}{l}\text { 4-6 layer } \\
\text { thick }\end{array}$ & $\begin{array}{l}\text { 3-5 layer } \\
\text { thick }\end{array}$ & $\begin{array}{l}\text { 3-6 layer } \\
\text { thick }\end{array}$ & $\begin{array}{l}\text { 2-5 layer } \\
\text { thick }\end{array}$ & $\begin{array}{l}\text { 1-3 layer } \\
\text { thick }\end{array}$ & $\begin{array}{l}\text { 3-5 layer } \\
\text { thick }\end{array}$ & $\begin{array}{l}8-15 \\
\text { layer } \\
\text { thick }\end{array}$ & 6-8 layer thick \\
\hline Pericycle & $\begin{array}{l}\text { 2-3 layer } \\
\text { thick }\end{array}$ & $\begin{array}{l}\text { 3-5 layer } \\
\text { thick }\end{array}$ & $\begin{array}{l}\text { 3-5 layer } \\
\text { thick }\end{array}$ & $\begin{array}{l}\text { 2-4 layer } \\
\text { thick }\end{array}$ & $\begin{array}{l}\text { 2-3 layer } \\
\text { thick }\end{array}$ & $\begin{array}{l}\text { 2-7 layer } \\
\text { thick }\end{array}$ & $\begin{array}{l}\text { 2-8 layer } \\
\text { thick }\end{array}$ & 2-5 layer thick \\
\hline
\end{tabular}




\begin{tabular}{|c|c|c|c|c|c|c|c|c|}
\hline Xylem & $\begin{array}{l}\text { 3-6 layer } \\
\text { thick }\end{array}$ & $\begin{array}{l}\text { 1-3 layer } \\
\text { thick }\end{array}$ & $\begin{array}{l}\text { 2-4 layer } \\
\text { thick }\end{array}$ & $\begin{array}{l}\text { 2-5 layer } \\
\text { thick }\end{array}$ & $\begin{array}{l}\text { 1-3 layer } \\
\text { thick }\end{array}$ & $\begin{array}{l}\text { 2-4 layer } \\
\text { thick }\end{array}$ & $\begin{array}{l}\text { 1-3 layer } \\
\text { thick }\end{array}$ & 1-3 layer thick \\
\hline Phloem & $\begin{array}{l}\text { 4-9 layer } \\
\text { thick }\end{array}$ & $\begin{array}{l}\text { 5-8 layer } \\
\text { thick }\end{array}$ & $\begin{array}{l}\text { 4-7 layer } \\
\text { thick }\end{array}$ & $\begin{array}{l}\text { 3-5 layer } \\
\text { thick }\end{array}$ & $\begin{array}{l}\text { 2-3 layer } \\
\text { thick }\end{array}$ & $\begin{array}{l}\text { 4-7 layer } \\
\text { thick }\end{array}$ & $\begin{array}{l}5-15 \\
\text { layer } \\
\text { thick }\end{array}$ & 5-8 layer thick \\
\hline
\end{tabular}

